Gediminas Vitkus, Jüratè Novagrockienë*

Military Academy of Lithuania

Institute of International Relations and Political Science, University of Vilnius

\title{
The Impact of Lithuania on EU Council Decision-Making*
}

\begin{abstract}
The article presents the results of the research which, in a defined sense, aimed at estimating and characterizing Lithuania's impact on EU Council decisions. Two tasks were tackled during the research. First, it was intended to identify the position of Lithuania and preferences of its representatives within the informal EU decision-making network. Second, it was sought, if possible, to evaluate the capability of Lithuania "to make an impact" on the EU Council decisions at least in two aspects (political-teleological and administrative-organizational).

In the course of the research it was established that the Lithuanian representatives in the EU Council most often informally communicate with their neighbours, i.e. the Baltic and Scandinavian countries and especially with Poland; therefore, they remain at the periphery of the informal EU Council decision-making network. Lithuania's interests have a rather narrow specialization and, consequently, it remains only slightly "interesting" for the core decision-makers. This, however, does not give grounds to claim that Lithuania's influence is null and void.

This situation is also partially affected by the problems associated with the capabilities of Lithuania "to make an impact," which were recorded in the respondents' questionnaires. However, alongside certain teleological and administrative problems, it should also be stated that after in-depth interviews and opinion polls, the research data revealed quite a few positive aspects and tendencies. That is why the problems that were noticed and identified during the research do not seem to be fatal or irresolvable.

Finally, apart from all the relativeness of the results obtained, the present research was important not only in terms of its content, but also in the methodological sense. The formulated methodology and approbated methods that are efficient for the research of informal communication as well as its manifestations and can be related to the degree of the impact of the member state might serve as the basis and the starting point for further studies of similar character.
\end{abstract}

\footnotetext{
* Dr. Gediminas Vitkus - Head of the Political Science Department of the Military Academy of Lithuania, Professor at the Institute of International Relations and Political Science of the University of Vilnius. Address: Šilo 5a, LT-10322 Vilnius, Lithuania, tel.+370-5-2103569, e-mail: gediminas.vitkus@tspmi. vu.lt; Dr. Jürate Novagrockiene is a assoc. professor of the Political Science Department of the Military Academy of Lithuania and director of the Strategic Research Center. Address: Šilo 5a, LT-10322 Vilnius, Lithuania, tel. +370-5-2103571, e-mail: jurate.novagrockiene@tspmi.vu.lt

${ }^{* *}$ The research was commissioned by the Ministry of Foreign Affairs of Lithuania and executed in AugustDecember 2007. The publication was prepared with kindly permission of the Client.
} 


\section{Introduction}

The relevance of the topic has been determined by the fact that it was the first time in the practice of the activity of the Lithuanian governmental institutions that a unique experience of participation in the European Union decision-making process was gained, which until then could be only theoretically contemplated and speculated on. It is common knowledge that in the period of preparation for the membership and negotiations on the membership, this activity of the public administration was widely promoted to society and finally "was sold" with the successful referendum on 10-11 May 2003. A widely used argument was that having become a member of the EU, Lithuania would get "a seat at the table" where important decisions to the whole of Europe were made, which also partially contributed to the success of the referendum. Nevertheless, there were quite a few sceptics who held the opposite view and claimed that the EU membership was more of a formality and without participation in the decision-making process no real changes in the implementation of national interests could be expected. In terms of its resources and even the scope of its interests, Lithuania is too small and thus will have to work no less than it had before in order to satisfy its interests. So, after over two years of a full-fledge membership, a rather extensive practical experience has been gained and a possibility not only for blindfolded speculation, but for a "closer" look at what this "seat at the table" implies as well as for the practical verification of who had been right has been made.

The problem of quality assessment regarding Lithuania's participation in the EU policies is formulated here, but in a broader sense, it is the problem of the relationship quality between the EU as an entity and a concrete member state. It should be stressed at the outset that at the theoretical level, a specific role of member states in the EU activities does not raise serious debates. Although there is no agreement between the two key schools looking into reasons for integration - "intergovernmentalism" and "supranationalism" - as to who nation-state or "supranational" institutions - has more importance in the integration process, all of them, however, hold the same view that it is impossible to manage without having a certain (i.e. more active or more passive, more oriented to national interests or common values) model of the state activity.

On the other hand, neither of the two has put forward a single more concrete hypothesis or model regarding the ways on how to empirically study and assess the interaction between member states and the Union as well as its effect on both the entire integration and development of individual states. It is understandable, in the theory analyzing the reasons for integration, that this is not an important issue since here, as a rule, the emphasis is essentially laid on purely quantitative differences between the "ideal" and highly generalized types of the state activity. At the empirical level though, the situation if far more confusing. 
Simon Bulmer and Christian Lequesne hold the opinion that all this "confusion" can be conceptualized in empirical analysis where two main relationship types between the European Union and member states - "outside-in" and "inside-out" - can be distinguished. Then, according to the above-mentioned scholars, having viewed the already existing empirical EU and nation-state relationship research, one can conclude that the outside-in type research, usually referred to as "Europeanization" studies, is obviously prevailing. ${ }^{1}$ Meanwhile, the "inside-out" relationship type research that aims at resolving essential methodological problems of empirical research - to formulate hypotheses and identify variables - as these authors claim is of yet among the most significant directions of future EU research. According to Bulmer and Lequesne, such studies are so far rather scarce. ${ }^{2}$

Nevertheless, after a more thorough search, rather interesting examples of these few research studies were discovered on the basis of which and with a corresponding modification of their ideas, attempts were made to work out a strategy for this particular research of the influence of a particular member state (in this case, Lithuania) on EU decisions.

First, in search of the answer to the question on how to estimate the influence of a member state on the EU as well as trying to determine in what way a member state manages "to nationalize" (or "utilize") the EU for its needs, we employed the so-called "policy networks" approach, which has already been rather widely used. Although, according to Tanja Börzel, who attempted to systematize application options of the "policy networks" approach, it is difficult to say what it constitute "a mere metaphor, a method, an analytical tool or a proper theory ${ }^{3}$, but in our case, a common definition that "policy networks" are "a set of relatively stable relationships which are of non-hierarchical and interdependent nature linking a variety of actors, who share common interests with regards to a policy and who exchange resources to pursue these shared interests acknowledging that co-operation is the best way to achieve common

\footnotetext{
${ }^{1}$ The book "Adapting to European Integration: Small States and the European Union", published in 1998 by the Dutch scientists Kenneth Hanf and Ben Soetendorp, can be pointed out as a distinct example of "Europeanization" and adaptation of EU states. The collective monograph "The Lithuanian Path to the European Union" published in 2004, which summarizes Lithuania's experience in preparation and negotiations could be regarded as the most significant among research works and studies dealing with the Lithuanian case. Certain aspects of the then future membership of Lithuania are also discussed in the book. Attention should be given to the section of the book written by Ramūnas Vilpišauskas "Lithuania in the Policy of the European Union: National Interests and Intergovernmental Coalitions". For apparent reasons, however, at that time the author was able to review only the experience of Lithuania's participation in the work of the Convent. The book "Enlargement and Europeanization of the European Union" published in 2003 according to the doctoral thesis by Klaudijus Maniokas is worth mentioning in this context too.

${ }^{2}$ Bulmer S., Lequesne Ch., "New Perspectives on EU-Member State Relationships", Questions de recherché / Research in question, 2002, January, No. 4, p. 28, http://www.ceri-sciences-po.org/publica/question/ qdr4.pdf, 18.12.2007.

${ }^{3}$ Börzel T., "Organizing Babylon - on different conceptions of policy networks", Public Administration, 1998, vol. 76, No. 2, p. 253.
} 
goals" $" 4$ is valuable enough. Assuming that actors participating in the EU Council decision-making process, i.e. representatives of member states and EU institutions, they have also formed a relatively stable "network", an informal network, then the position that Lithuania holds in that network might help judge about the impact of Lithuania on EU Council decisions.

It is evident that the identification of the informal "network" existing and operating within the EU Council could be a separate and complicated task. However, this time too, we managed to employ the results of earlier research studies. As far back as in 1993-1994, the Belgian researchers Jan Beyers and Guido Dierickx carried out a significant research and identified this informal network. ${ }^{5}$

It is true that the main conclusion made by the authors was not a striking one. In fact, in the practice of the preparation and adoption of decisions in the EU Council an informal "web", the centre of which comprises institutional actors (the Commission, the Presidency (then Belgium) and the Secretariat General of the Council) as well as the three major member states (the United Kingdom, France and Germany) has been formed. Meanwhile, at the periphery of the "web" are the smaller member states of Northern Europe and all member states of South Europe (Ireland, Luxemburg, Italy, Spain, Portugal and Greece). An intermediate position in this web is taken by Denmark, the Netherlands (and, most probably, Belgium) that are "closer" to the centre only due to their constant communication with the UK and Germany (but not France!), and hence they should be included into a separate specific group of "North Europe". Informal communication in the centre of the "web" is more intensive - the actors communicate more extensively and exchange information and opinions more often. Meanwhile, the actors at the periphery are either of "little" interest or "not interesting at all" to others, whereas their mutual informal communication is insufficient. Naturally, this also affects the impact of certain actors.

On the other hand, this conclusion is extremely important to other similar research studies in both the content and methodological sense. In terms of the methodological and methodical sense, the conclusions of the present research were drawn on the basis of surveys of employees from permanent representations of 12 EU member states working in Brussels on their mutual informal communication, on its quality and quantity. As a consequence, a verified and reliable guideline for drawing up a strategy for this particular research is obtained. And as far as the content is concerned, the results of this research could be an excellent starting point for the studies of the present-day processes. As a matter of fact, it has been a long time since the Belgian researchers carried out their studies and likewise, the EU itself has undergone several enlargements.

\footnotetext{
${ }^{4}$ Ibid., p. 254.

${ }^{5}$ Beyers J., Dierickx G., "Nationality and European Negotiations: The Working Groups of the Council of Ministers", European Journal of International Relations, 1997, vol. 3, No. 4, p. 435-471; Beyers J., Dierickx G., "The Working Groups of the Council of The European Union: Supranational and Intergovernmental Negotiations", Journal of Common Market Studies, 1998, vol. 36, No. 3, p. 289-317.
} 
Nevertheless, we suppose that there are no sufficient grounds to believe that once identified, the informal network suddenly disappeared and no longer exists. We are not inclined to believe that the 1995 enlargement could, in some way, essentially distort it. Austria, Sweden and Finland, most probably, joined the intermediate, semi-peripheral group of the "northerners" rather than the peripheral one.

The great 2004 enlargement, no doubt, is a different matter. Yet, it should be kept in mind that either the position of the "new member states" itself or their size quite naturally places all, without exception, new member states within the second-rate periphery. This, however, does not indicate that with time the situation is not likely to change. There will be changes and, in fact, they are already taking place with the newcomers "spreading" within the already existing network and making the peripheral space more differentiated. It is hardly believable that they will get into the communication "core". Even so, it is evident that the Vysegrad group countries (except, probably, Slovakia) are likely to seek that. Hence, the study of the Lithuanian case could also help partially answer this question.

This is how, due to the need to assess the already accumulated Lithuania's experience of the EU membership and based on the research results obtained by scientists who studied similar problems, the aim of this research, the results of which are presented here, was in a defined sense, to estimate and characterize Lithuania's impact on EU Council decisions.

In order to achieve this objective, two tasks were tackled during the research. First, it was attempted to identify the position of Lithuania and the preferences of its representatives within the informal EU decision-making network. This task was planned to be solved by preparing a certain questionnaire and surveying the widest possible circle of the Lithuanian representatives at different levels of the EU Council.

Second, it was decided to still verify and approbate research presumptions by means of qualitative unstructured interviews with the Lithuanian executives and officials who have already gained considerable experience while representing the country in various EU Council negotiations. In AugustSeptember 2007, discussions were held with six officials and the information provided by them essentially confirmed the fact that the impact of the country on EU Council decisions largely depends on the ability of a representative to establish maximally optimal informal professional and personal contacts with negotiation partners, actively participate in debates going on in the "couloirs" and in formal sittings.

The qualitative interviews also revealed additional aspects of the problem, which were obviously valuable and could supplement the planned research as well as point out certain quality and form aspects of Lithuania's impact on EU Council decisions. After the analysis of the interview data, it became obvious that not only the activeness of the officials, but also the level of the preparation of the member state itself (in this case, that of the political administrative authority) "to make impact" is of great importance. In this 
respect, the replies and ideas provided by the interview respondents suggested the idea that this research, essentially that of "process" quality, should be supplemented with the task of the assessment of the "abilities" quality. To put it simply, an additional idea emerged: to collect data concerning the fact whether the Lithuanian representatives, whose task is to properly represent and defend the interests of Lithuania, are themselves always aware of Lithuanian objectives and interests in each particular case and whether the coordination system of EU affairs in Lithuania "services" and "supports" them properly and efficiently enough.

This circumstance determined the second task of the research which could be defined as an attempt, within the realms of possibility, to assess the ability of Lithuania "to make an impact" on EU Council decisions in the political and teleological, administrative and organizational aspects.

Six in-depth interviews were conducted and in November 2007 a questionnaire was sent out via e-mail to 115 respondents. The respondents were all officials who are included in the Order of the Minister of Foreign Affairs of the Republic of Lithuania, "On the Approval of the Lists of Representatives of the Ministry of Foreign Affairs who Present the Position of the Republic of Lithuania in the Committees and Working Groups of the Council of the European Union and the European Union Commission" (11 June 2007, No V-63) and also all officials mentioned in the Internet website of the Representation of the Republic of Lithuania to the European Union (http:/ / www.eurep.mfa. lt/index.php?-399404298, 19.11.2007). Only 38 out of the sent 115 questionnaires were received. Three of them were not completed properly, so the analysis provided here is based only on the data of 35 questionnaires. $^{6}$

The first part of the article analyzes the position of Lithuania within the informal EU decision-making network based on the preferences of its representatives. The second part deals with the identified problems concerning Lithuania's preparation "to make impact" on EU decisions in the political and teleological as well as administrative and organizational aspects.

\footnotetext{
${ }^{6}$ It is evident that due to the small number of the completed questionnaires, the results of this research could be considered only relatively reliable. The research itself, though, aiming at encompassing the areas of representation of Lithuanian interests only within the competence of the Ministry of Foreign Affairs, had been planned as a pilot research, as assessed on the scale of all Lithuanian institutions working with the EU.
} 


\section{Lithuania within the Informal EU Council Decision-Making Network}

\subsection{The Importance of Informal Communication}

The impact of the member state on EU Council decisions can be estimated in different ways. However, in the present research, the data obtained from the respondents about their informal contacts and relations with representatives from other member states was chosen as the main indicator of the impact "quantity".

The primary aim was to acquire a clear understanding of how the Lithuanian representatives in general appreciate the importance of informal communication. The assumption that the majority of respondents attach greater significance to informal meetings and sittings was confirmed: 59\% of the respondents did not agree that formal discussions during sittings are more important than conversations in the couloirs (Figure 1). And 35\% of the respondents were neutral, which means they acknowledged the importance of both formal and informal contacts.

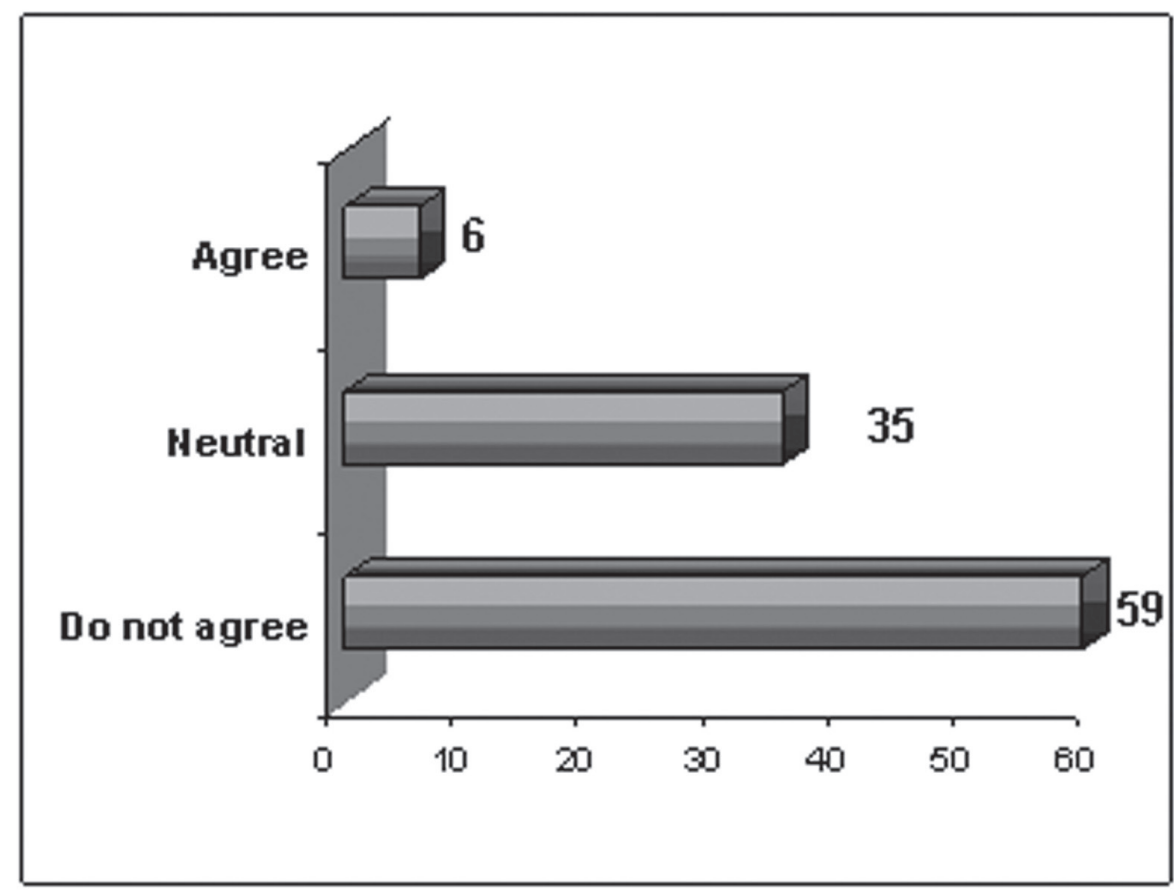

Figure 1. Do you agree with the statement that what is spoken during formal sittings is much more important to the content and quality of EU decisions than what is discussed informally in the couloirs of the sittings? (\%) 
This attitude of the majority of the respondents is confirmed by the opinion about the importance of informal negotiations in the couloirs as compared with formal talks. 55\% of those surveyed held that it was during informal meetings that decisions were actually taken. $24 \%$ neither denied nor supported this statement. Only 21\% of the respondents disagreed with it (Figure 2). The prevailing opinion in the survey data was that considerably more is achieved during informal discussions than in merely formal work.

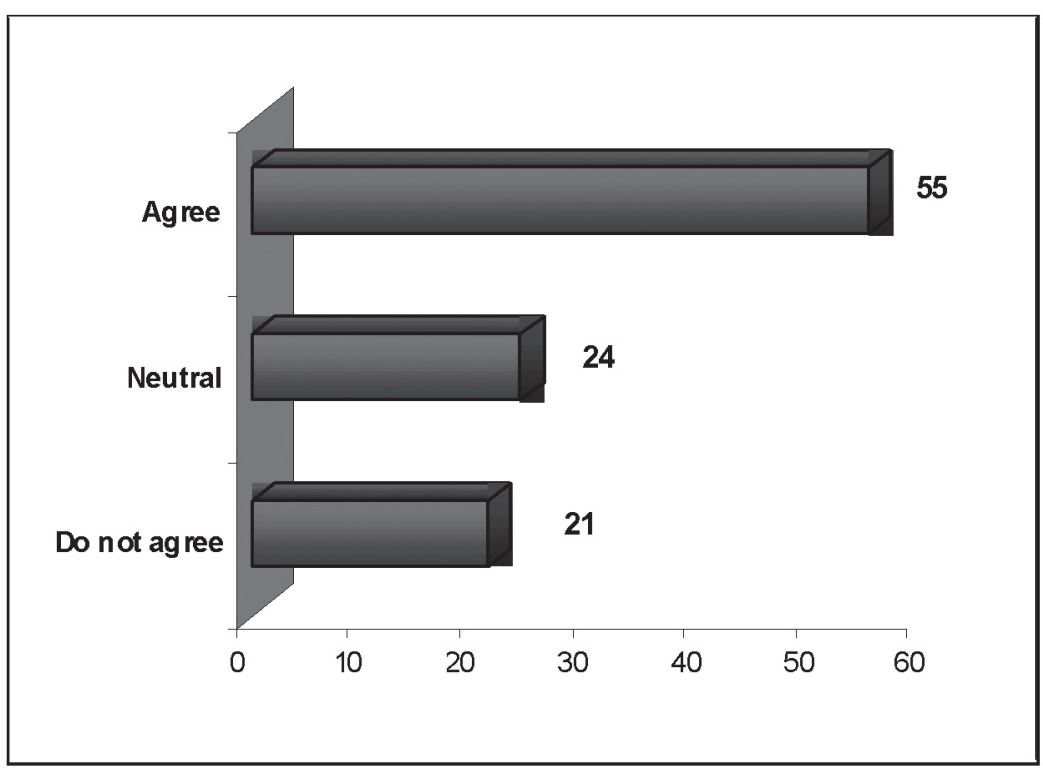

Figure 2. Do you agree with the statement that key decisions at any EU Council level are made during informal couloirs negotiations between member state representatives, whereas official negotiation sessions and sittings are only a formality? (\%)

\subsection{Lithuania within the Informal Communication "Network" of EU Countries}

Firstly, this part of the article shows which EU member states are "closest" and "farthest" from Lithuania. Secondly, here the network of informal contacts of Lithuania is compared with the impact network within the European Union identified by the above-mentioned Beyers and Dierickx. Figure 3 shows that the EU Council decision-making core comprises the EU institutions - the Presidency, the Commission, the Secretariat-General of the Council - and the three EU member states: Germany, France and the United Kingdom. The group 
of Northern Europe ${ }^{7}$, whose exceptional influence is based on closer relations between the UK and Germany ${ }^{8}$, includes the Netherlands, Belgium, Denmark, Sweden, Finland and Austria. Ireland, Luxemburg, Italy, Spain, Portugal and Greece constitute the EU decision-making periphery. A common distinctive feature of these countries is their closer contacts and orientation towards France, and a lower level of activity provided that their national interests are not involved. Meanwhile, "the newcomers", whose situation for obvious reasons could not be included in the 1994 research, so far can be represented on the outside. It is likely that they "will spread" into the already existing groups. It is less probable that they will form a separate influence group and take a special position in the existing hierarchy.

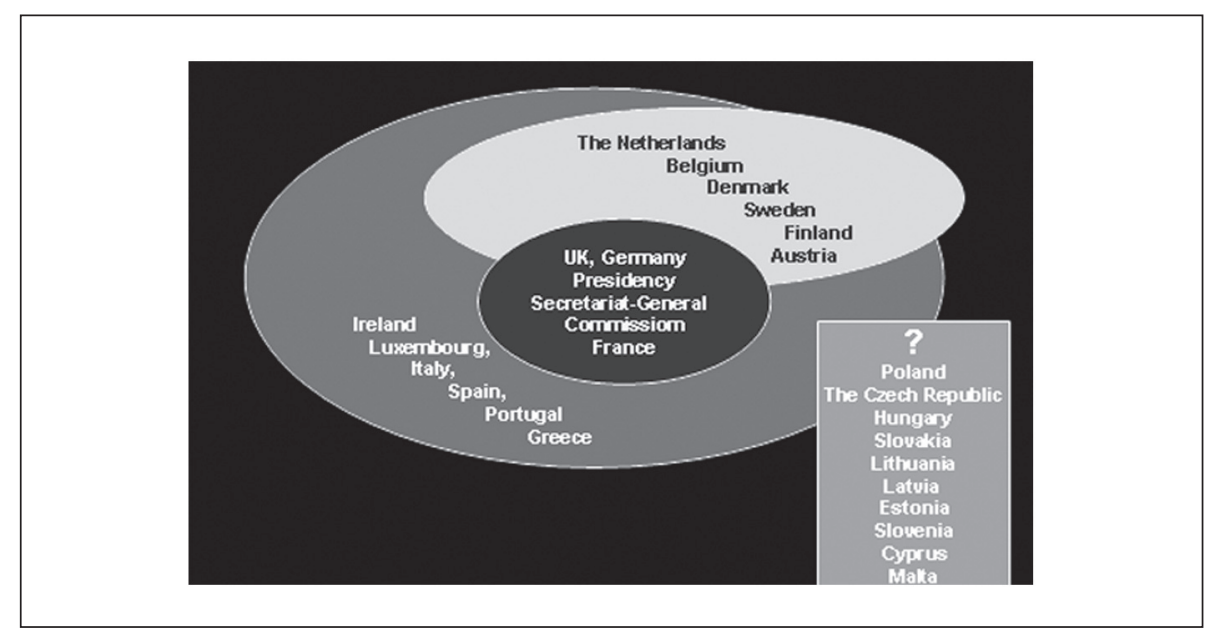

Figure 3. The informal decision-making network EU-15+10

Having in mind this informal network, the respondents were asked about the informal contacts they had with representatives of other member states. After the analysis and summary of the replies provided by the respondents, the results presented in Figure 4 were obtained. This rather confusing information can be simplified by means of the frequency index of informal consultations which can be computed counting one point for each per cent of "frequent" contacts, 0.5 point for each per cent of "rare" contacts and 0 points for the absence of contacts. ${ }^{9}$

The indexes of informal contacts between Lithuania and EU member states are presented in Table 1, while its position within the network of informal contacts is shown in Figure 5.

\footnotetext{
${ }^{7}$ Conventional title (GV\&JN).

${ }^{8}$ For the sake of accuracy it should be noted that the research of Beyers and Dierickx was carried out in 1994 when the EU comprised only 12 states. Therefore, making a slight concession, we will include the three EU states that joined in 1995 in the same group of "Northern Europe".

${ }^{9}$ For example, if $50 \%$ of the respondents indicated that they communicate with a certain country often, $20 \%$ rarely and $30 \%$ never, then the index will be $50+20 / 2+0=50+10=60$.
} 


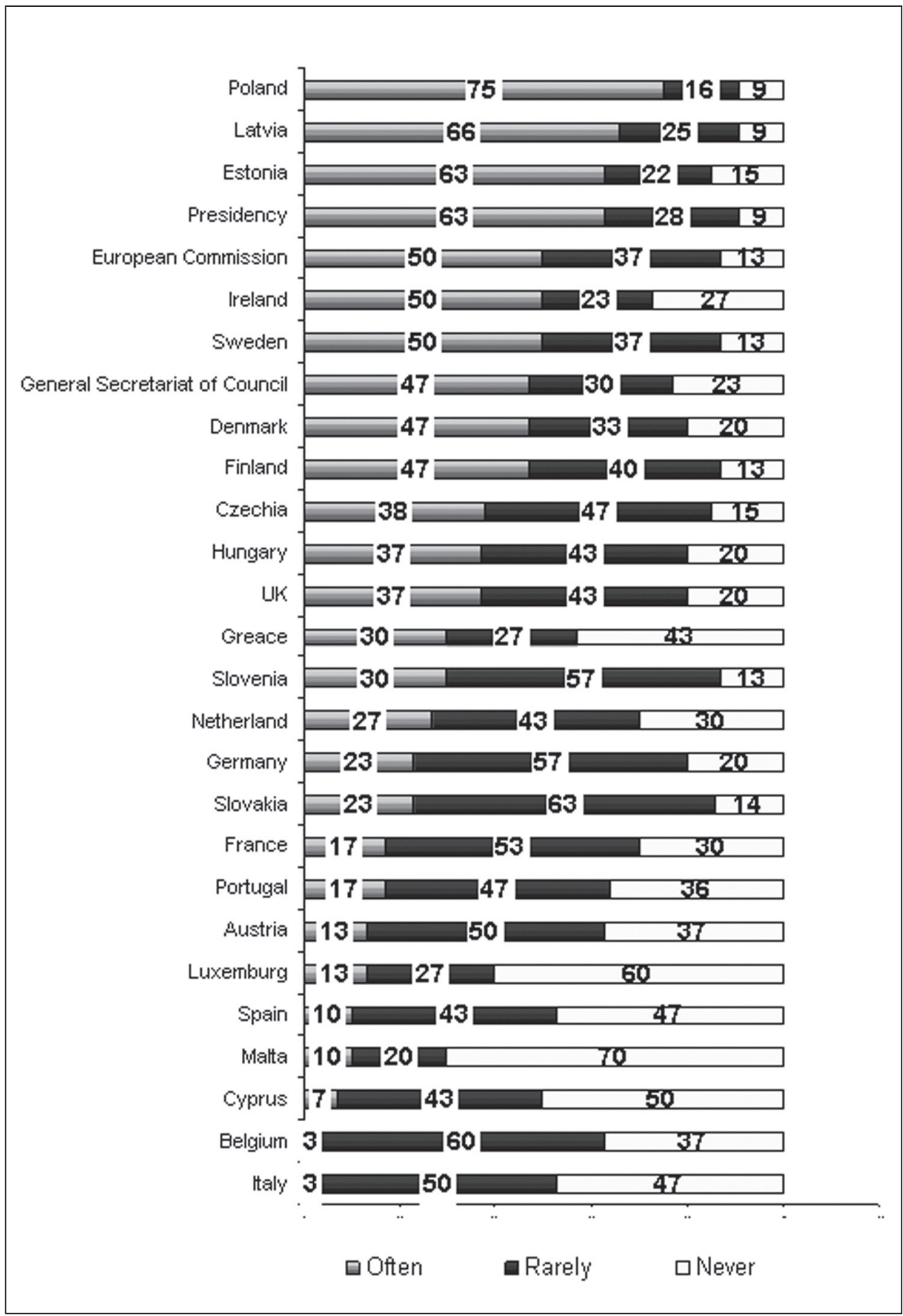

Figure 4. Frequency of informal contacts (as estimated by the Lithuanian representatives) (\%) 
Table 1. The frequency index of informal contacts (as estimated by the Lithuanian representatives) (\%)

\begin{tabular}{|c|c|}
\hline Member State / EU Institution & Frequency index \\
\hline Poland & 83 \\
\hline Latvia & 78.5 \\
\hline Presidency & 77 \\
\hline Estonia & 74 \\
\hline European Commission & 68.5 \\
\hline Sweden & 68.5 \\
\hline Finland & 67 \\
\hline Denmark & 63.5 \\
\hline Secretariat-General & 62 \\
\hline Ireland & 61.5 \\
\hline The Czech Rep. & 61.5 \\
\hline United Kingdom & 58.5 \\
\hline Hungary & 58.5 \\
\hline Slovenia & 58.5 \\
\hline Slovakia & 54.5 \\
\hline Germany & 51.5 \\
\hline The Netherlands & 48.5 \\
\hline France & 43.5 \\
\hline Greece & 43.5 \\
\hline Portugal & 40.5 \\
\hline Austria & 38 \\
\hline Belgium & 33 \\
\hline Spain & 31.5 \\
\hline Cyprus & 28.5 \\
\hline Italy & 28 \\
\hline Luxembourg & 26.5 \\
\hline Malta & 20 \\
\hline
\end{tabular}




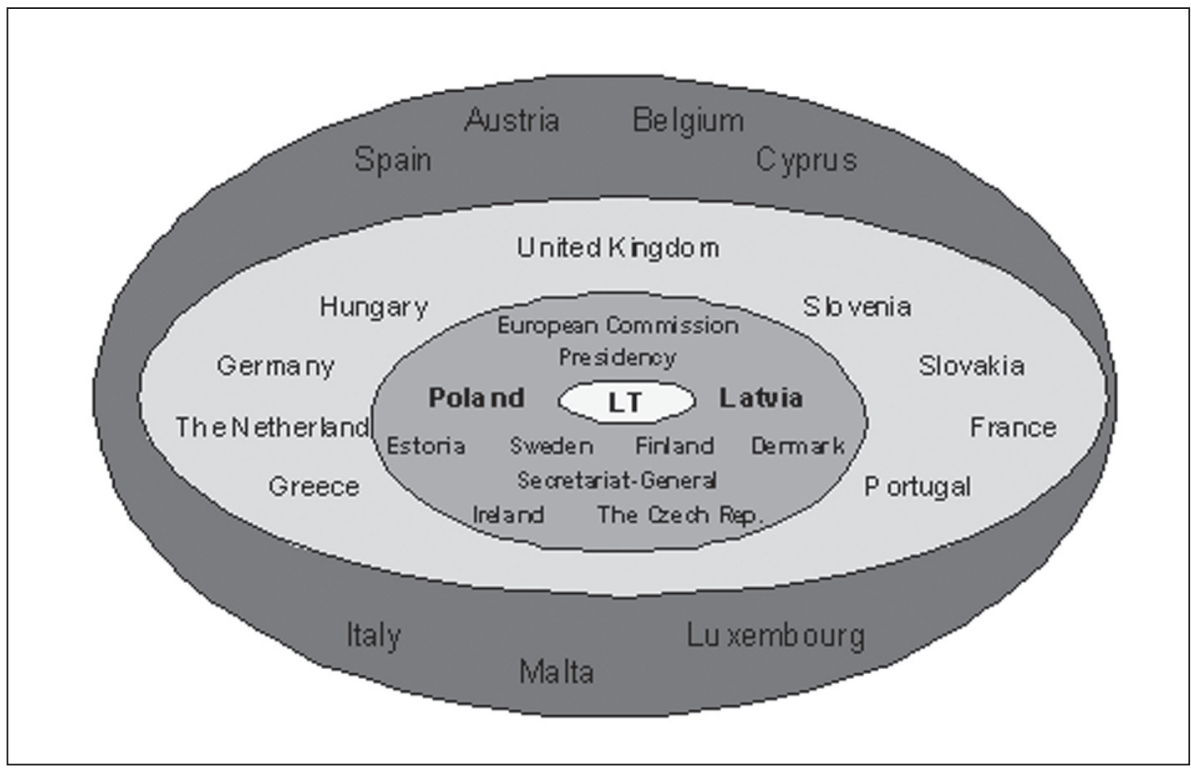

Figure 5. Frequency of informal contacts (as estimated by the Lithuanian representatives) (\%)

These results indicate that the Lithuanian representatives most often informally communicate with Poland and Latvia, also with the institutions organizing and coordinating the decision-making process as well as with the group of "North Europe". The frequency of informal contacts with the key major member states is lower. The "periphery" of Lithuanian contacts to a greater or lesser extent coincides with the "periphery" of the decision-making space of the EU itself.

Another question that the respondents were asked was more concrete and aimed at determining how often and with what representatives of other countries and EU institutions informal consultations were held on the initiative of the Lithuanian representatives themselves. The results obtained are presented in Figure 6. 


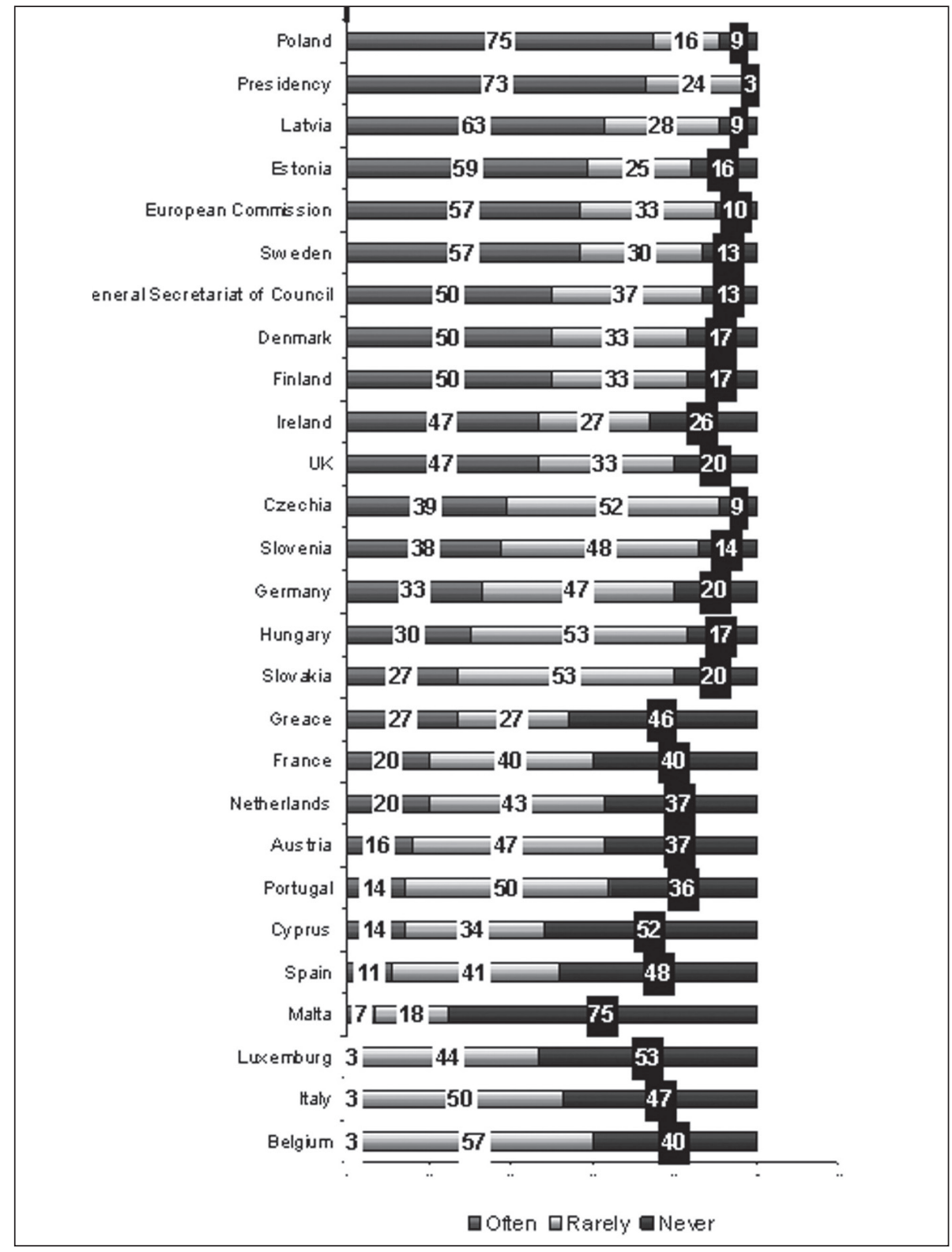

Figure 6. Informal contacts and consultations with representatives of other countries and EU institutions initiated by the Lithuanian representatives, (\%)

Although the distribution of the frequency of contacts is clear enough, it is possible, for the sake of simplicity, to employ the conventional frequency index and a graphic representation. These results are indicative of the direction of the initiative of Lithuania to establish and maintain informal contacts. In this 
case, the representatives of Lithuania aimed to primarily "settle affairs" with the Presidency (which seems logical), but afterwards most often seek informal contacts with Poland and Latvia. It is interesting (though hardly rational) that France stays at the periphery of the interest of Lithuanians (Table 2 and Figure 7).

Table 2. The frequency index of informal consultations with representatives of other countries and EU institutions held on the initiative of the Lithuanian representatives, (\%)

\begin{tabular}{|c|c|}
\hline Member State / EU institutions & Frequency index \\
\hline Presidency & 85 \\
\hline Poland & 83 \\
\hline Latvia & 77 \\
\hline European Commission & 73.5 \\
\hline Sweden & 72 \\
\hline Estonia & 71.5 \\
\hline Secretariat-General & 68.5 \\
\hline Denmark & 66.5 \\
\hline Finland & 66.5 \\
\hline The Czech Rep. & 65 \\
\hline United Kingdom & 63.5 \\
\hline Slovenia & 62 \\
\hline Ireland & 60.5 \\
\hline Germany & 56.5 \\
\hline Hungary & 56.5 \\
\hline Slovakia & 53.5 \\
\hline The Netherlands & 41.5 \\
\hline Austria & 40.5 \\
\hline Greece & 40.5 \\
\hline France & 40 \\
\hline Portugal & 39 \\
\hline Belgium & 31.5 \\
\hline Spain & 31.5 \\
\hline Cyprus & 31 \\
\hline Italy & 28 \\
\hline Luxembourg & 25 \\
\hline Malta & 16 \\
\hline
\end{tabular}




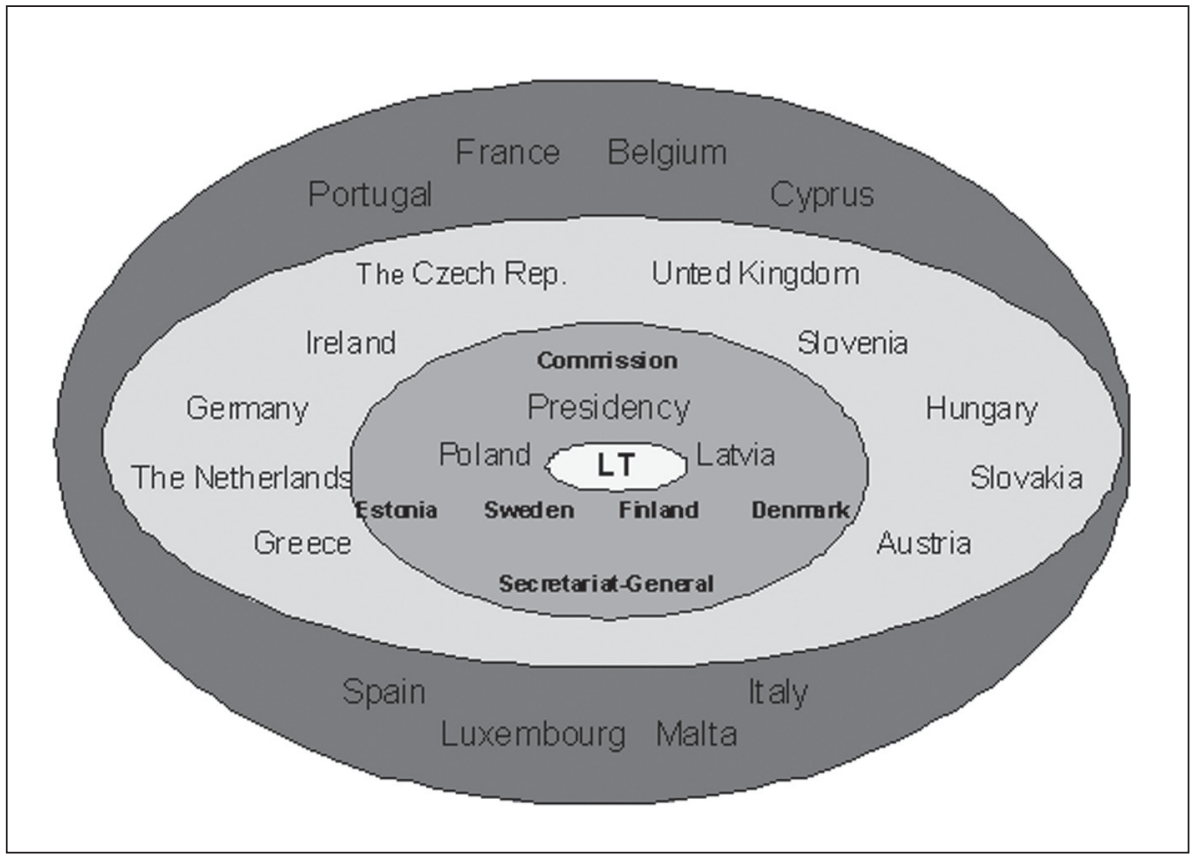

Figure 7. The frequency index of informal consultations with representatives of other countries and EU institutions held on the initiative of the Lithuanian representatives in on the chart

And finally, one more question was given to the respondents regarding the frequency of informal contacts, and was designed to define how often and also which representatives of which countries tried to establish and expand informal contacts with Lithuanians (Figure 8). 


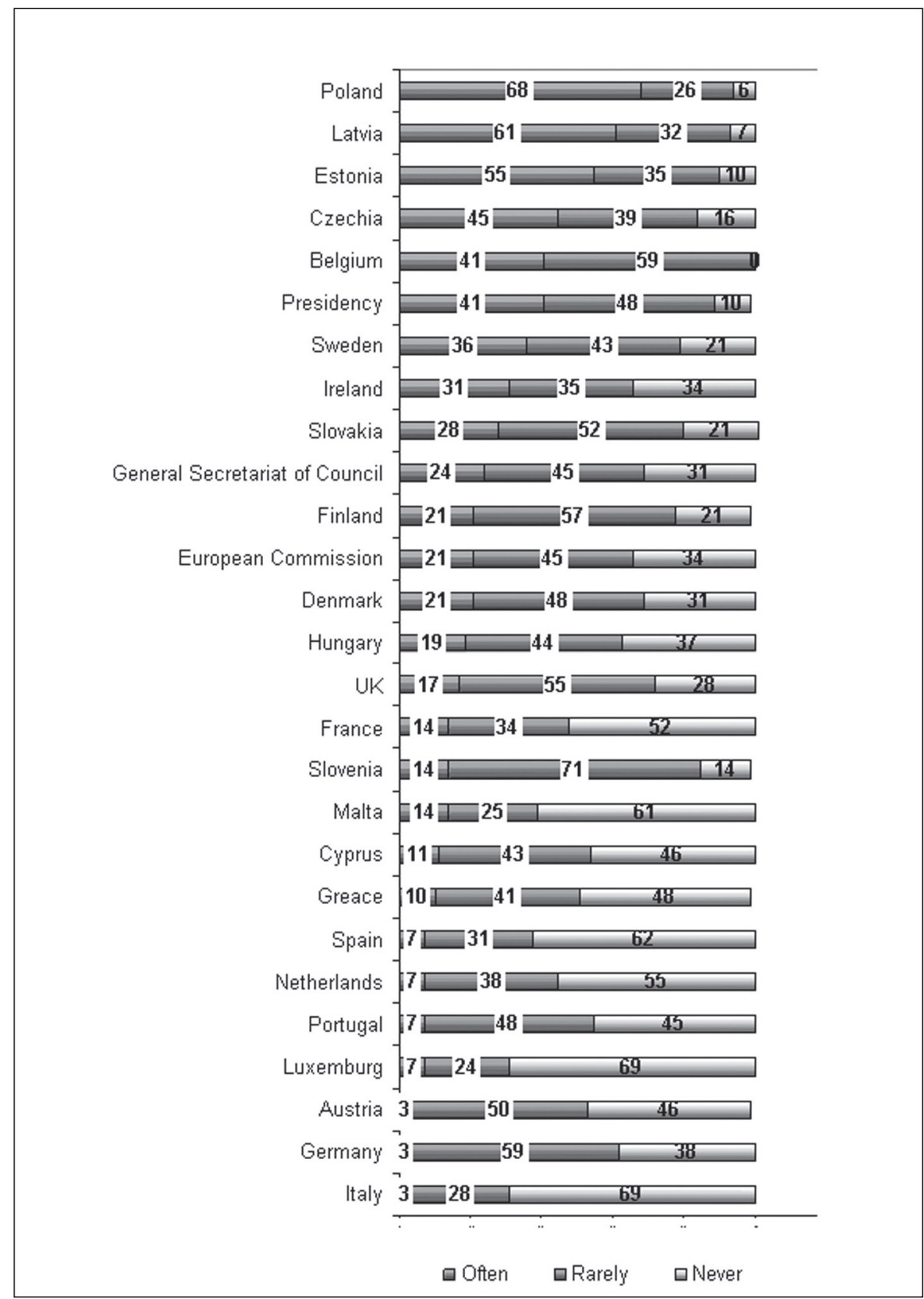

Figure 8. Informal contacts and consultations with the Lithuanian representatives initiated by representatives of other countries/institutions, (\%)

Having summed up these results according to the conventional frequency 
index, we can see from Table 3 and Figure 9 who out of other EU partners find Lithuanians "interesting". It is no wonder that we are interesting to our neighbours and the Presidency which ex officio "collects" all opinions. The attention of Sweden is far from surprising, but the high index of Belgium is totally unexpected. At the same time, it would be desirable to have higher indexes of Germany and France. A relatively high position of the United Kingdom could also be easily explained by the professionalism of the British diplomacy that is determined not to miss a single detail.

Table 3. The frequency index of informal consultations with Lithuanian representatives on the initiative of the representatives of other countries and EU institutions, (\%)

\begin{tabular}{|c|c|}
\hline Member State / EU Institution & Frequency index \\
\hline Poland & 81 \\
\hline Latvia & 77 \\
\hline Estonia & 72.5 \\
\hline Belgium & 70.5 \\
\hline Presidency & 65 \\
\hline The Czech Rep. & 64.5 \\
\hline Sweden & 57.5 \\
\hline Slovakia & 54 \\
\hline Slovenia & 50 \\
\hline Finland & 49.5 \\
\hline Ireland & 48 \\
\hline Secretariat-General & 46.5 \\
\hline Denmark & 45 \\
\hline United Kingdom & 44.5 \\
\hline European Commission & 43.5 \\
\hline Hungary & 41 \\
\hline Germany & 32.5 \\
\hline Cyprus & 32.5 \\
\hline France & 31 \\
\hline Portugal & 31 \\
\hline Greece & 30.5 \\
\hline Austria & 28 \\
\hline Malta & 26.5 \\
\hline The Netherlands & 26 \\
\hline Spain & 22.5 \\
\hline Luxembourg & 19 \\
\hline Italy & 17 \\
\hline
\end{tabular}




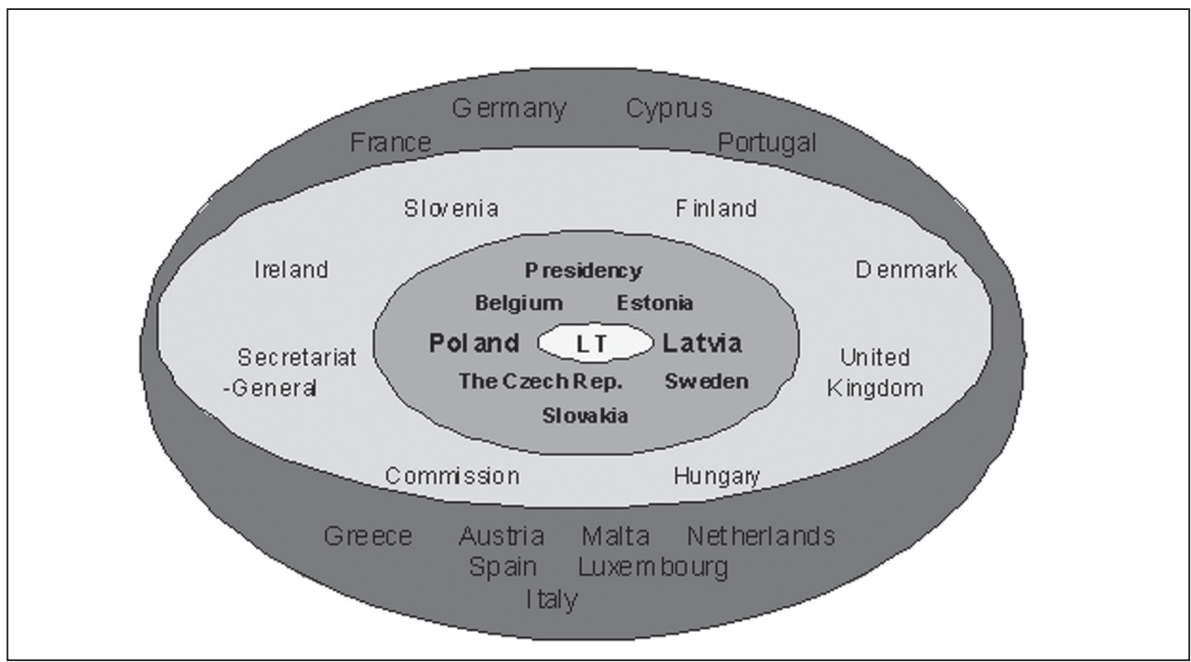

Figure 9. Frequency of informal consultations with Lithuanian representatives on the initiative of the representatives of other countries and EU institutions on the chart

A relatively peripheral place of Lithuania within the network of the Council of the EU can be partly explained by the very specifics of Lithuanian interests and the nature of the already gained expertise. The presented assessments in qualitative interviews and the respondents' answers to open questions in the questionnaire are particularly illustrative. We have, as it is, both sides of the medal - a shortage of expertise and a nearly developed specialization of the country. On the one hand, the narrowness of Lithuanian interests and a certain expert "range of vision" is emphasized:

...Lithuania has no expert knowledge and independent (own) information sources about the major part of the world and it is not able to take an active part in shaping the policy pertaining to these regions. It also does not participate in solving the most important issues concerning EU CFSP tasks - the Middle East peace process, Iran, Burma, etc. ${ }^{10}$

On the other hand, the importance of Lithuanian regional policy is revealed and the gained experience is acknowledged:

I see when the eyes of Lithuania start sparkling - let's do it, let's remedy it here, it is natural that these are all neighbourhood matters, Russia, here is energy. These issues are more interesting for us, such is the specialization in Lithuania, though it is nowhere recorded, it does exist. This becomes natural, if it is seen that the delegate gets awake when a discussion about these issues starts. Ah, this is an issue about Belarus, and, Lithuania, have you got anything to say? Such specialization is, I would think, acknowledged in the Corepers ${ }^{11}$.

\footnotetext{
${ }^{10}$ Questionnaire No.2.

${ }^{11}$ Interview No.1.
} 
These thoughts are also confirmed by the fact that the concept of "single issue country", which obviously has a negative connotation and defines Lithuania as a country of very limited influence, seemed acceptable to $34 \%$ of respondents, $37 \%$ of them adhered to a neutral position and only less than onethird did not agree with the statement (Figure10.). Therefore, it can be assumed that the discourse about Lithuanian interests "in width" is still too meagrely developed first of all by those who shape and implement the Lithuanian policy. It is understandable that their behaviour and inspirations determine the corresponding assessment by representatives of other EU countries.

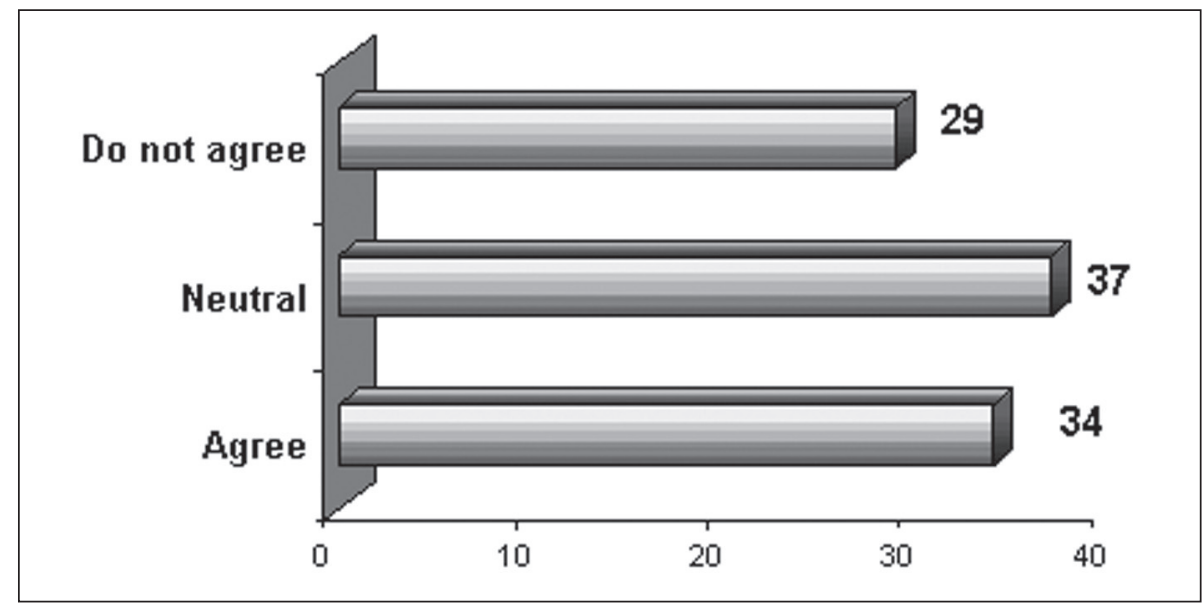

Figure 10. Would you agree that during the first three years of the membership Lithuania was a single issue country? (\%)

Summing up, it is possible to state that Lithuania has not yet completely "hatched out" of the newcomers' group and remains of low interest to the decision-making core. Contacts with the group of "North Europe" are less developed than it is sometimes assumed. From the point of view of the major member states, we are neatly "floating" in the waterway of the United Kingdom. As it is fitting, we ignore the periphery of the EU (Irish and Greeks being a pleasant exception). It is obvious that possibilities for more intensive dealings with France and Germany have not been taken advantage of. Trying to wedge ourselves alongside the Irish into the "North Europe" group, we should also better utilize the phenomenon of the "Belgian" attention.

From this point of view, the eternal dilemma of near and distant perspective remains - to strengthen the area in which Lithuania has already gained a certain acknowledgement or to develop new areas of possible impact. Each of the choices has its pluses and minuses. In order to develop a broader expertise, the problem of financial and human resources arises. Aiming at specialization, it is necessary to face up the fact that Lithuania will stay "silent" and will voice no opinion on many issues actual for the entire Europe. It is a matter of political choice. 


\section{2. "Impact-Making" Problems of Lithuania}

As the research data indicates, the construction of informal networks and establishment of personal contacts usually depend on the initiative and activeness of Lithuanian representatives in the EU Council, in other words, on personal qualities of people working in Brussels. On the other hand, the success of their activity in no lesser a degree depends on the standpoint of Lithuanian institutions as well as on the capability to train the assigned people to adequately perform their mission. Further presented are the problems that can be rather easily resolved by attempts of institutions coordinating and preparing Lithuania's representation in the EU, though it seems that they have not been given sufficient attention yet.

\subsection{Conception of the Objectives and Interests of the Country}

First, both the experts that gave qualitative interviews and the respondents of questionnaires were sceptical about Lithuania's capabilities to exert a considerable impact on EU Council decisions. As many as $49 \%$ of the respondents indicated that the impact of Lithuania was slight, $42 \%$ - that it was balanced and only $6 \%$ that it was large (Figure 11 ).

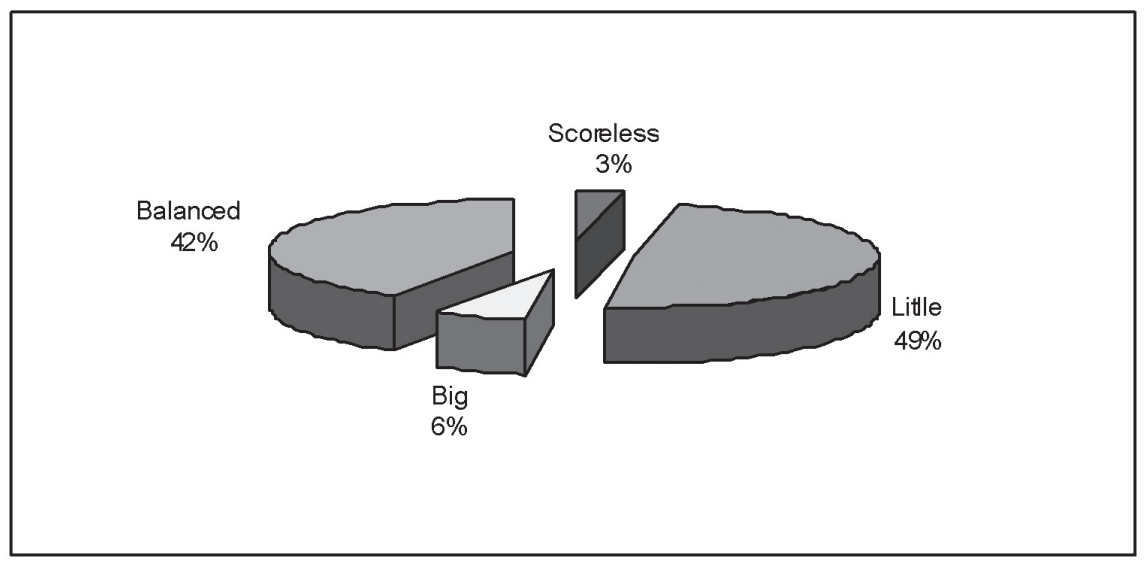

Figure 11. Estimate of Lithuania's impact in the EU Council in the five-point system, (\%)

The reasons surounding the slight impact of Lithuania, in the opinion of other respondents, were identified in their answers to the open question regarding why Lithuania's impact in the EU Council is slight. Among other reasons, which will be discussed further on, insufficient awareness of what it is that we want holds again an important place. In one of the qualitative in- 
terviews it was claimed that the impact of Lithuania is weak because it often does not know what it seeks:

...we do not know what our objective is and what objective then the European Union becomes. At times we want this and then we want that. What is our trade mark? What is our identity ${ }^{12}$ ?

Here we present some of the opinions from the questionnaires:

- We do not yet really know what we want (in the professional sense) and what our priorities are. And one of the distinct hindrances to the representation system is not the relationship among the representation links (working group - Coreper minister), [...] but between the representation links and the LT system (for completely understandable reasons - old system, new needs, shortage of human resources, etc.). ${ }^{13}$

- We are unable to sufficiently clearly understand and formulate our interests (particularly on horizontal-type issues), Lithuania's policy is still being shaped exceptionally on the basis of sector-level principles, ${ }^{14}$

- There are no clearly formulated and consistently implemented general priorities of national policy (whether LT is for further liberalization of the EU economy, etc.); therefore, different ministries (ministers) treat similar situations differently; there is also lack of consistency in representing LT positions in different working groups or Council formations ${ }^{15}$.

Therefore, first, attempts were made to find out to what extent, in the opinion of the respondents, Lithuania within the three years of its membership, has been aware of what it is aspiring to. This aspect is important because the formulation of tasks for Lithuanian representatives in the EU depends on the grounds of clear understanding of the objective and interests,.

A calculated $44 \%$ of the respondents believed that as early as the first year of the membership, Lithuania knew what it was seeking, 35\% had no opinion or couldn't give an unambiguous answer to this question ${ }^{16}$, and $21 \%$ agreed with the statement that Lithuania did not know what it is aiming at (Figure12). Because of the small number of the respondents, it can be assumed that such a distribution of answers can reflect opinions of Lithuanian representatives supervising different areas and working with different institutions.

\footnotetext{
${ }^{12}$ Interview No.5.

${ }^{13}$ Questionnaire No.10.

${ }^{14}$ Questionnaire No.15.

15 Ibid.

${ }^{16}$ A couple of the respondents added that it was difficult to give unambiguous answers to some questions.
} 


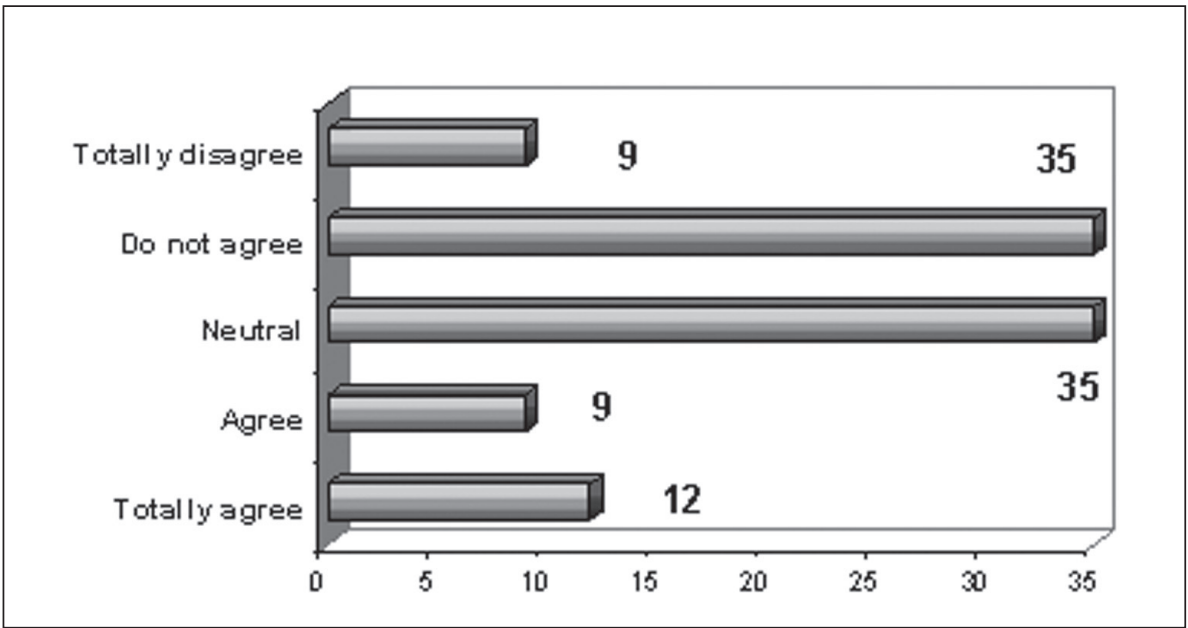

Figure 12. Would you agree with the statement that during the first three membership years, Lithuania could not make a serious impact on EU decisions because most often it was not capable of answering the question about its own aspirations? (\%)

On the other hand, the clarity of interests generated by official institutions, as well as the self-awareness of people working at different levels of the EU Council and their identification with the positions they represent serve as an important influence-increasing factor. In this case, the key premise to be verified was that officials representing Lithuania can successfully participate in the EU Council decision-making process not only when they themselves imagine clearly and exactly what they should seek, but they themselves also support that position.

The answers, received to the question regarding whether their opinion used to coincide with the instructions received from Lithuanian institutions and departments, confirmed that the degree of their identification is sufficiently high. The absolute majority of the respondents replied that their opinion always $(6 \%)$, very often $(42 \%)$ and often $(43 \%)$ coincided with the instructions received from Lithuania (Figure 13). Thus, it seems that $90 \%$ of Lithuanian representatives in the EU Council are clearly informed and are aware of the interests of Lithuania. Undoubtedly, this is an important prerequisite for successful work of the representatives in the Council. 


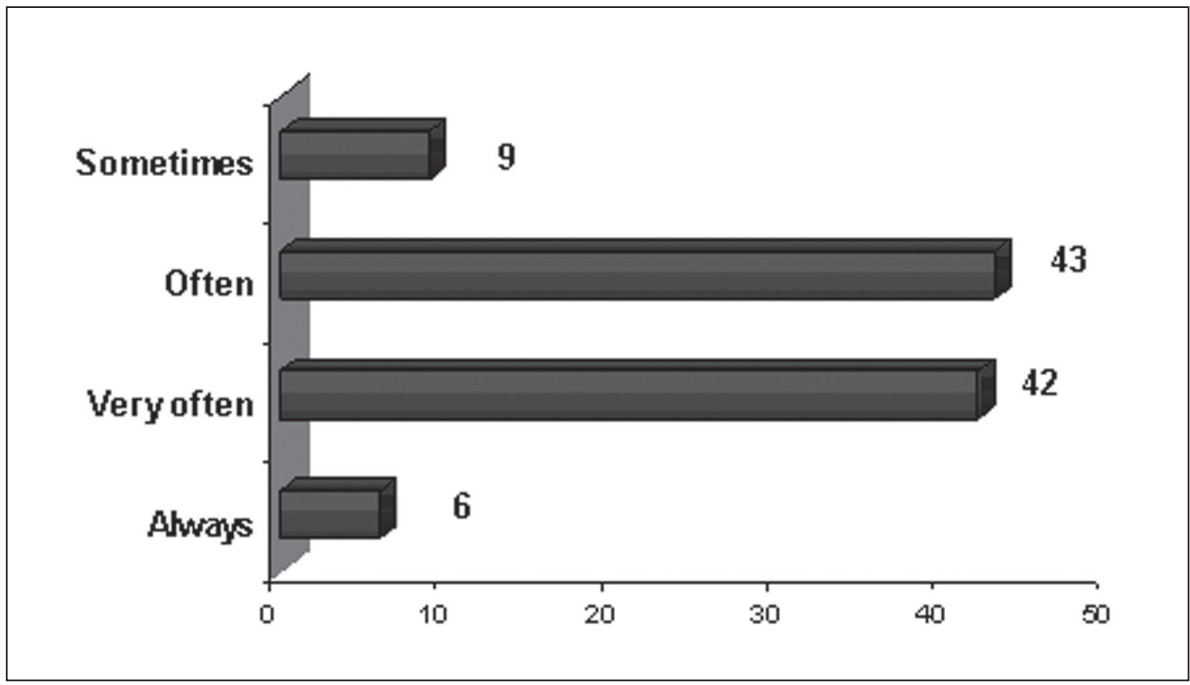

Figure 13. Did your, as negotiator's and expert's, opinion use to coincide with instructions received from Lithuanian institutions and departments? (\%)

Meanwhile, attempts to find out the direction of the respondents' selfawareness, in case their opinions did not coincide with the official policy, generated the answer that the majority of Lithuanian representatives would desire a more liberal (51\%) and more radical (26\%) position of Lithuania on certain issues (Figure 14). This leads to a preliminary conclusion that the official position of Lithuania is so far more conservative than the personal opinion of its representatives.

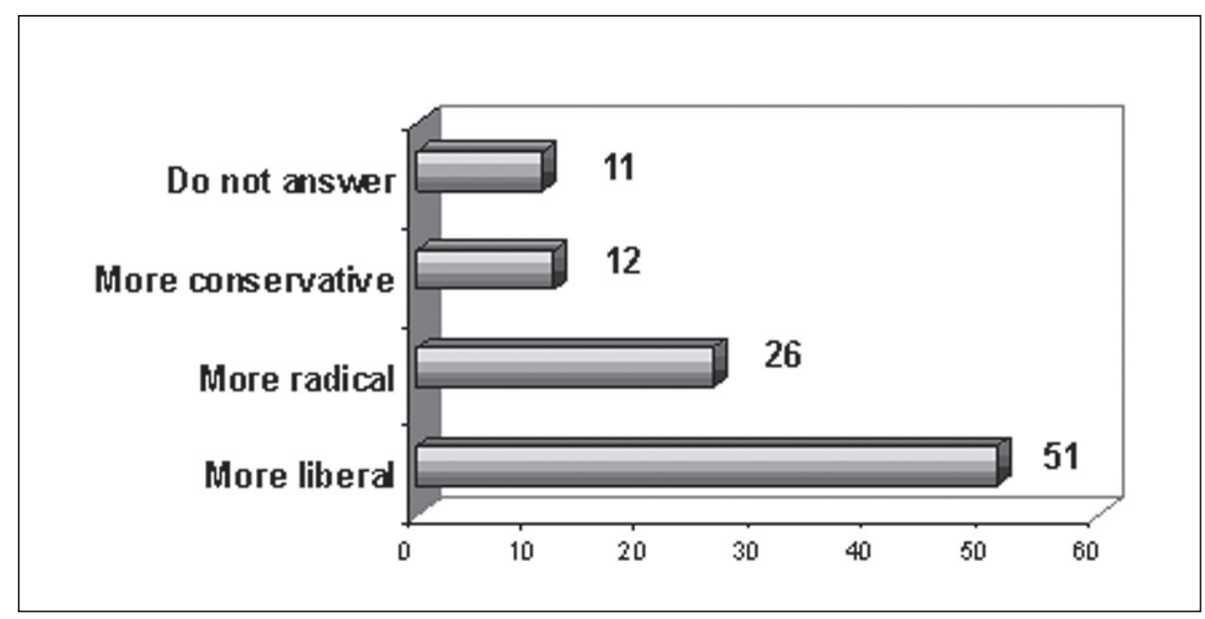

Figure 14. In case your opinion and the official position did not coincide, you held the view that the position of Lithuania should be, (\%) 
Generalizing the "teleological" part, it is possible to point out that the reason for the weakness of the impact recorded in one of the qualitative interviewsinsufficient self-awareness of the country and its representatives - seems to have only partly been confirmed. Yet, further analysis of the data indicates that it is inseparable from the instructions received by Lithuanian representatives in the EU Council, and communication with Lithuanian institutions. In other words, problems with coordination, organization and administration arise.

\subsection{Coordination of the Work of Lithuanian Representatives in the EU Council}

The presence of organizational problems was identified during in-depth interviews. Therefore, in putting questions to a wide circle of the respondents, the main attention was focused on making the current shortcomings concrete.

First, it is obvious that the EU affairs coordination system in Lithuania is not estimated sufficiently well. Though $83 \%$ of the respondents think that this system is operating (Figure15), only 34\% of the respondents believe that the system is functioning well. A caculated $43 \%$ find its operation satisfactory, whereas $20 \%$ - poor (Figure 16).

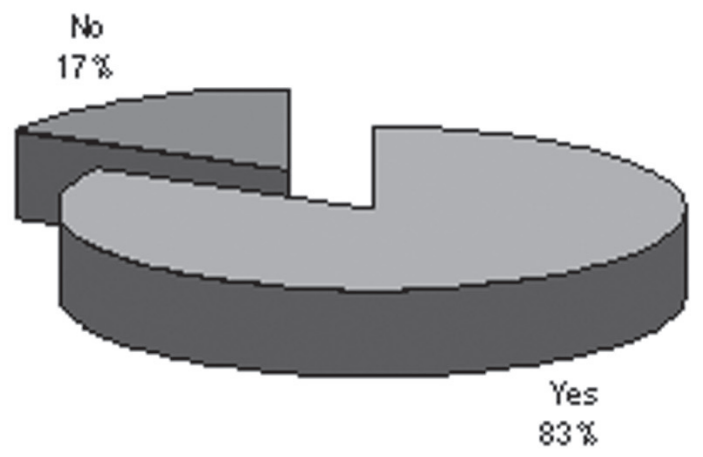

Figure 15. Does the EU affairs coordination system actually operate in Lithuania? (\%) 


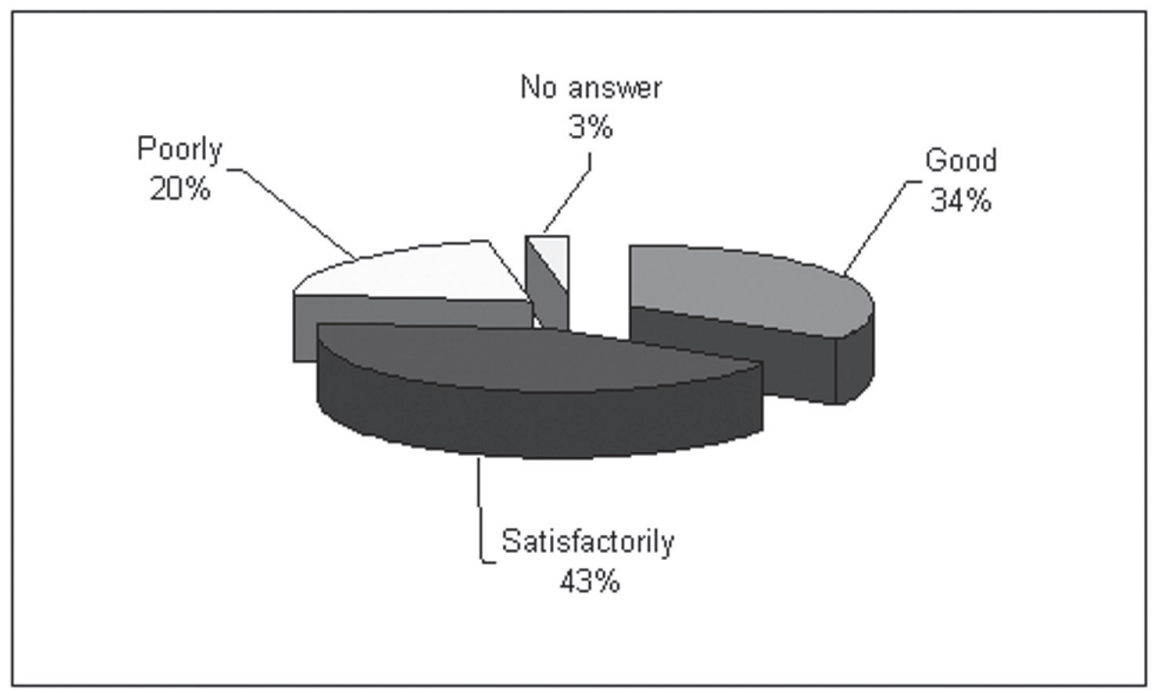

Figure 16. How would you estimate the current capability of the EU affairs coordination system in Lithuania? (\%)

An additional indicator, illustrating the ineffectiveness of the coordination system as well as the understanding of the interests of Lithuania, is the opinion of the respondents about the support they received while preparing for concrete sittings of working groups and committees.

As shown in Figure 17, a greater part of the respondents indicated that they had a sufficiently clear understanding of their tasks: only $23 \%$ "sometimes" know what they should seek, but none of the respondents indicated the extreme position "never".

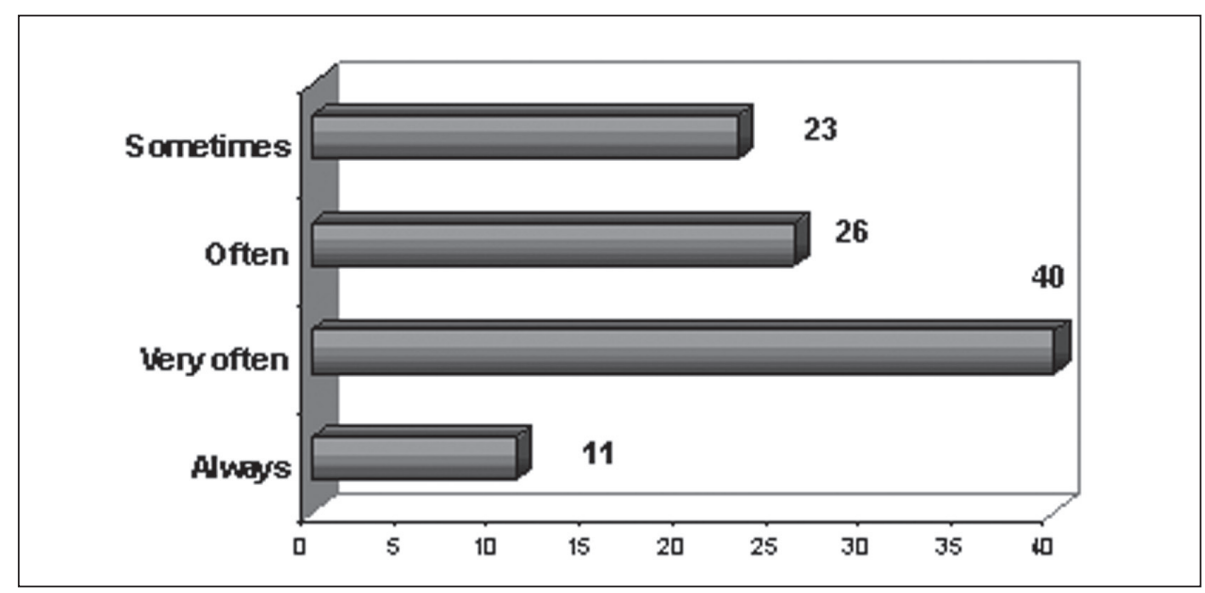

Figure 17. How many times did you have to go to sittings with a clear and unambiguous understanding about what Lithuania should seek? (\%) 
As a proof of effectiveness, the fact can be noted that as many as $95 \%$ of the respondents indicated that, even with only an hour left before the sitting, it was possible to always, very often and often get more accurate instructions on the Lithuanian position (Figure 18). In other words, it is possible to make an assumption that Lithuanian institutions formulate a rather clear position of Lithuania. The possibility to make it more accurate until the very point of negotiations is also positive.

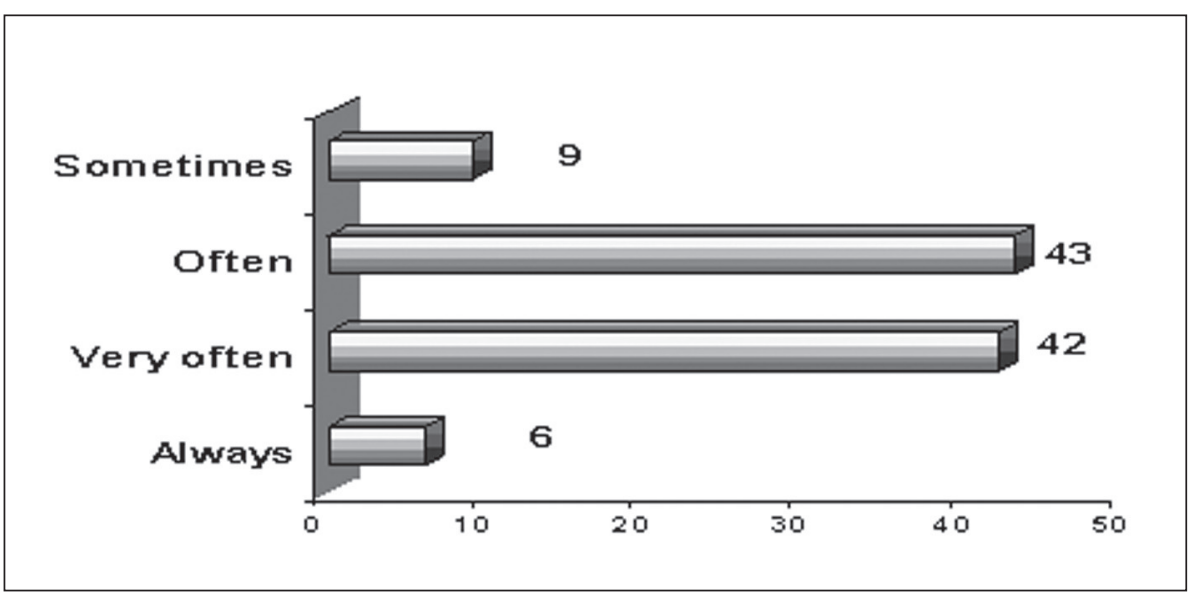

Figure 18. Is it possible, say, with only an hour before the sitting, to effectively get a more accurate position of Lithuania? (\%)

As the respondents indicated, they were also fairly well informed in terms of flexibility of the position represented by Lithuania. A caculated $6 \%$ of the respondents knew to what extent the position of Lithuania could be "always", 39\% - "very often" and 34\% - "often" changed during negotiations (Figure 19).

The analysis of the answers, regarding instructions received from $\mathrm{Li}-$ thuania, raised doubts regarding whether the representatives of Lithuania are well supported by administrations and organizations. A caculated $6 \%$ of the interviewees indicated that they very often, and as many as $77 \%$ often faced controversial instructions (Figure 20). This casts doubts on the frankness of answers to the previous question and leads to an assumption about a shortage of horizontal relationship among departments, absence of consensus, or inadequate attention given to the preparation of a common position on one or another issue. 


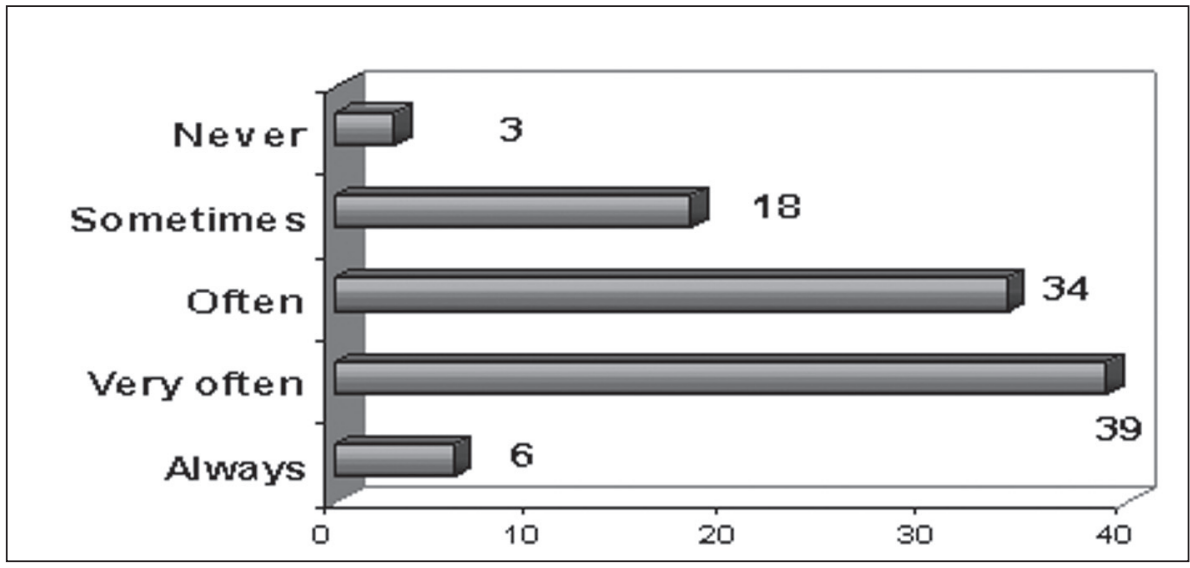

Figure 19. Did you clearly know before the negotiations what concessions you could make and to what extent you could change the initial position during them? (\%)

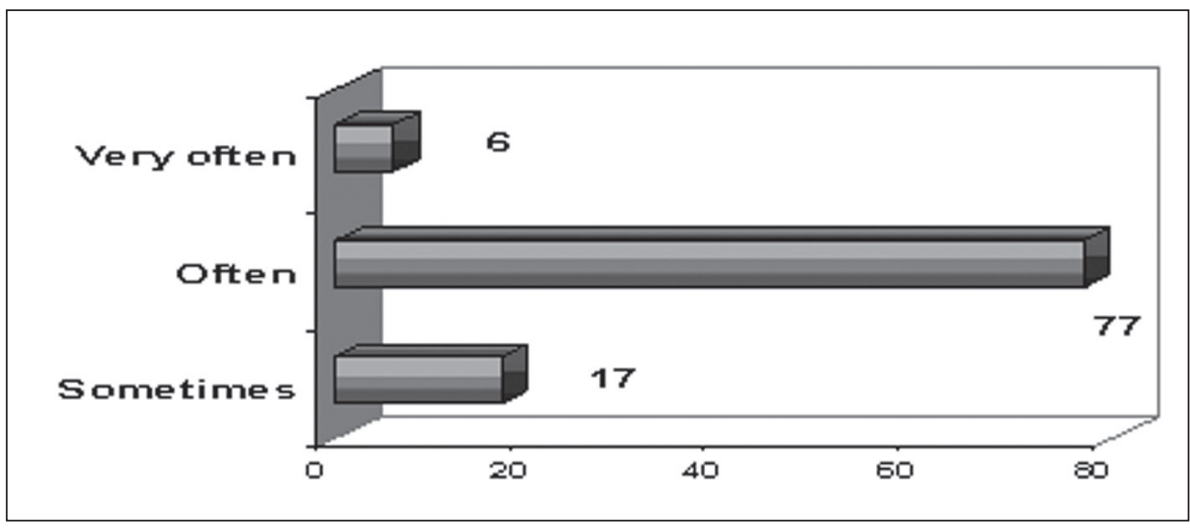

Figure 20. Have you ever faced controversial instructions? (\%)

Summing up, it should be pointed out that the EU affairs coordination system of Lithuania should not be estimated exceptionally on the basis of the respondents' opinion though, in any case, it is very important. Anyway, they are very important "consumers" of the production generated by this system. Therefore, positive aspects recorded here, such as capability, effectiveness and flexibility do not preclude one from naming such urgently-to-be-settled problems as a better communication between departments and coordination, a shortage of which manifests its self in an excessive amount of controversial instructions. 


\subsection{Preparation of Lithuanian Representatives in the EU Council for Work in Brussels}

While talking with experts during more thorough interviews, one more organizational aspect of "impact-making" quality surfaced - the issue of the preparation of Lithuanian representatives for work in Brussels. Therefore, research was conducted on how Lithuanian representatives are prepared for work in the EU Council. Only 3\% of the respondents felt very well prepared, $31 \%$ - prepared when they first went to work in Brussels, and 15\% admitted that they went unprepared. A caculated $51 \%$ of the respondents considered themselves to be only partially prepared (Figure 21).

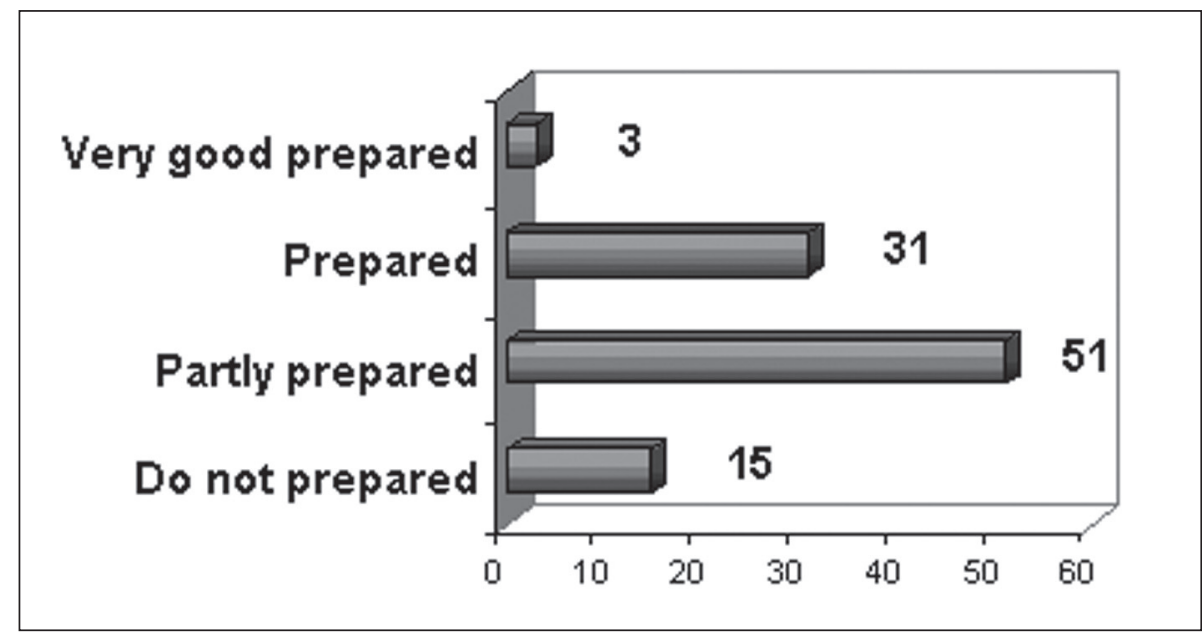

Figure 21. When you first went to work in Brussels and had to participate in the EU Council negotiations, did you feel sufficiently or insufficiently prepared for that? (\%)

It turned out that a uniform training system for representation of Lithuanian interests in the EU Council is non-existent. Only half of the respondents indicated that they had attended an organized course. A calculated $49 \%$ of the respondents did not get any training (Figure 22), besides, only $12 \%$ of those who were purposefully trained estimated the preparatory measures "very well" and 38\% - well. A calculated 38\% of the respondents claimed that they had not been trained for work in Brussels (Figure 23). 


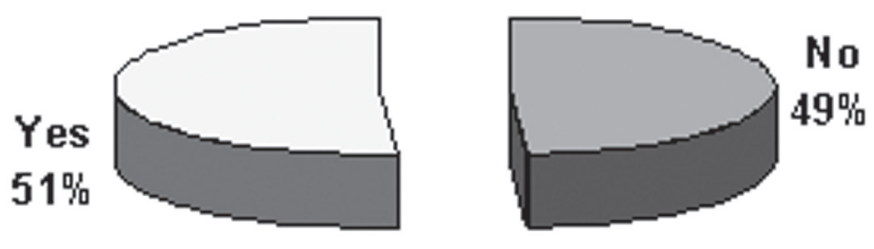

Figure 22. Has any training been organized for you to prepare for work in the EU Council? (\%)

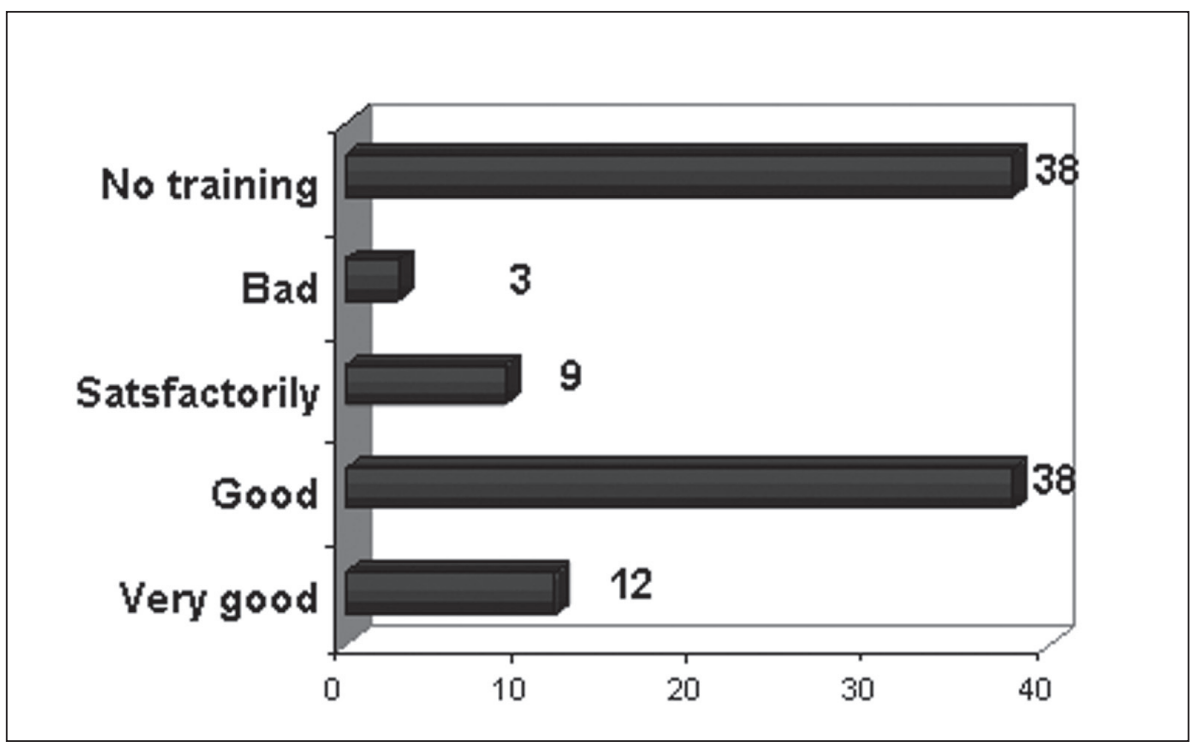

Figure 23. How do you estimate the training that had to help you prepare for the participation in EU Council negotiations? (\%)

Keeping in mind the fact that the degree and nature of the preparation of those assigned to work in the EU Council were different due to various reasons, attempts were made to establish whether there existed any compensatory mechanisms that could at least partially eliminate preparation and qualification flaws and transfer the experience and skills gained by predecessors sufficiently effectively. However, as the respondents claimed, during the several membership years, neither the available experience of the EU membership or preparation for the membership, nor the data bank (74\%), nor accumulation and transfer mechanism $(74 \%)$ have so far been established (see Figure 24 and Figure 25). Yet, as indicated by the questionnaire data, informal channels for the exchange of experience do exist and apparently function well. This was indicated by $75 \%$ of the respondents (Figure 26). 


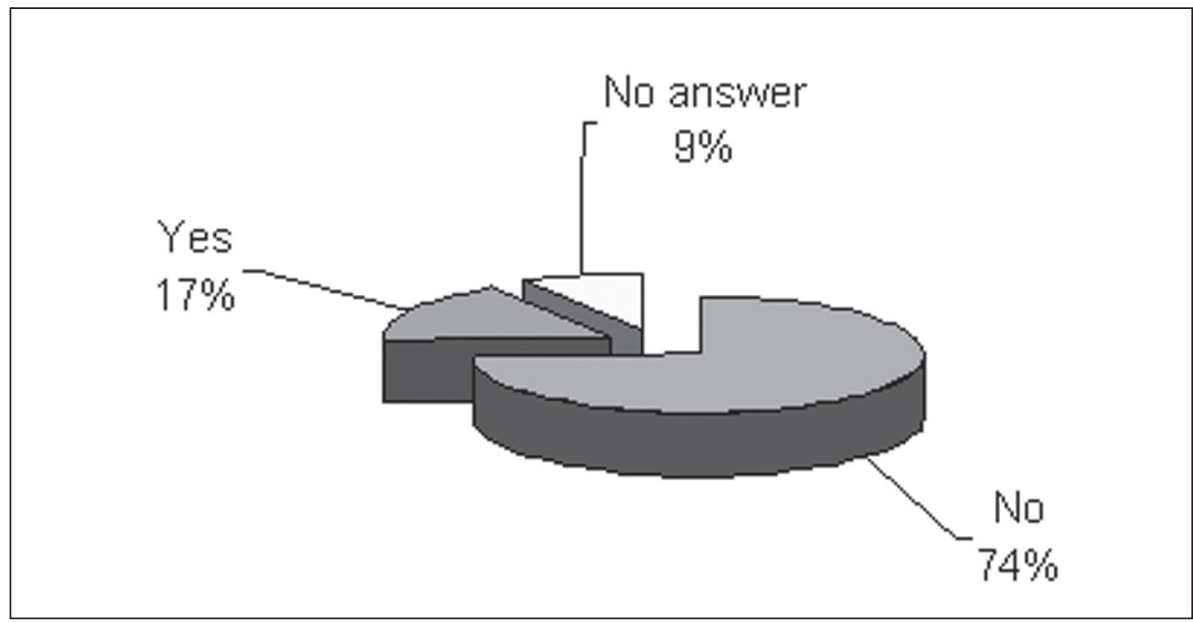

Figure 24. Has a data bank of the gained experience and established personal relationships and contacts in the Lithuanian representation and other institutions been created? (\%)

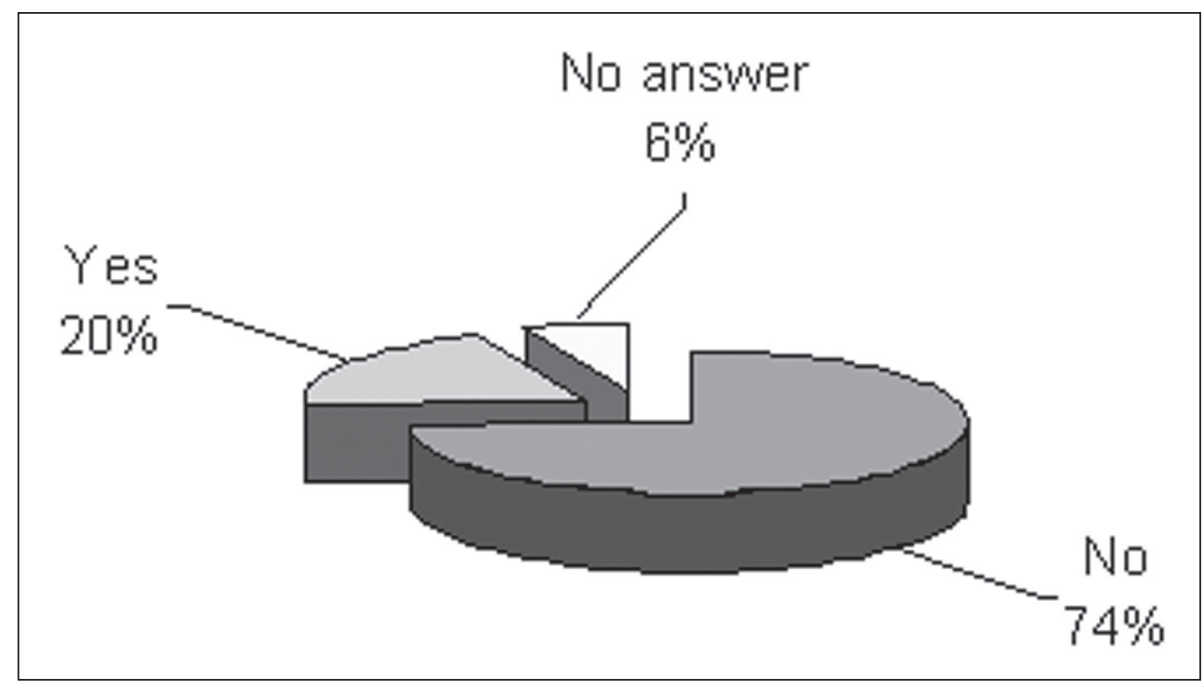

Figure 25. Is there a formal mechanism for the transfer to followers of the gained experience and established personal relationships and contacts? (\%) 


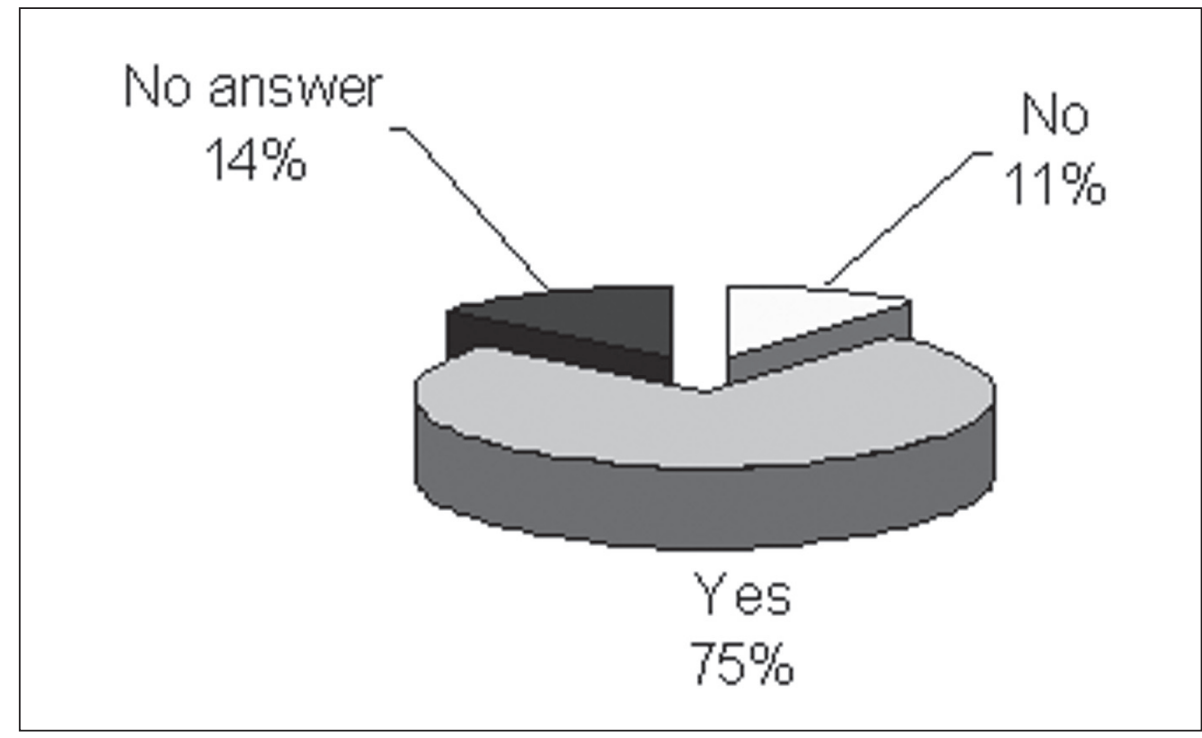

Figure 26. If such a mechanism does not exist, is the information about the established personal relationships and contacts transferred informally to followers? (\%)

Summing up the presented data, an unavoidable necessity to formalize the accumulation and transfer of work experience in the EU Council becomes apparent. It is probable that the success of Lithuanian representatives in Brussels in negotiations concerning the decisions made largely depends on the familiarization with the decision-making "machinery" in the EU Council.

\section{Conclusions}

The experience of the Lithuanian representatives, gained during their work in institutions of the European Union, and Lithuania's impact, determined by that experience on decisions taken in the EU Council are an extremely interesting yet so far only a slightly researched phenomenon. Such studies enable not only to record shortcomings and eliminate flaws, but also to regard Lithuania as if from the outside, to compare it with other EU member states and identify the real situation more accurately. Therefore, though scanty, this data is significant because, in a defined sense, it corrects our preconceived attitudes and convictions as to how and in what degree the EU impacts on Lithuania and, on the contrary, to what extent Lithuania is significant to the EU itself.

Besides, notwithstanding the relativity of the obtained results, this research was important in both the methodological and methodical sense. The formulated methodology and the approbated methods can serve as a basis and starting point for further research of a similar nature. 
The performed analysis of the data makes it necessary to admit that the involvement of Lithuanians in the informal communication "net" within informal structures of EU relationships could be more intensive. The majority of representatives (here we will dissociate ourselves from some astoundingly perfect exceptions) confirmed that they are most often inclined to informally discuss "matters" with their neighbours - Baltic and Nordic countries, particularly with Poland. Undoubtedly, this way cannot be regarded as a negative phenomenon, yet it is obvious that the scope of informal communication contacts should be broader.

The results once more confirmed that Lithuania's interests are of a rather narrow specialization; therefore, it remains of little "interest" to the EU decision-making core countries.

It was anticipated to find an explanation for such a situation by analyzing the issues of Lithuania's capability "to make an impact" presented in the questionnaires of the respondents. The analysis of the data revealed that:

- During the three years of the membership, representatives of Lithuania did not always clearly and exactly know what they should seek while working in the EU Council working parties;

- A better-tuned mechanism of the socialization of all Lithuanian representatives (notwithstanding the area under their supervision) with a wider scope of the interests of the country is in short supply;

- The system of EU affairs coordination and preparation for concrete sittings of working groups and committees and particularly the system of horizontal relationships between departments should be improved;

- The preparation of Lithuanian representatives for standing negotiations in the EU Council should be improved by paying particular attention to the development of informal communication skills;

- The continuity of Lithuanian representatives' work should be taken care of by improving and formalizing the order for the transfer of the gained experience and achievements of the predecessors.

It should be pointed out that apart from the identified teleological and administrative problems some definitely positive aspects have also been established. We met a group of competent, well-motivated and having a high level of preparation, representatives of Lithuania. A great part of the respondents confirmed that the Lithuanian EU affairs coordination system operates quite well, and its attributes such as capability, effectiveness and flexibility provide the administrative support in their everyday work. Therefore, the problems determined and identified during the research can be resolved sufficiently fast.

In conclusion, it should be stated that the data obtained makes it possible to claim that the impact of Lithuania on EU Council decisions is not null and void. It corresponds to the possibilities of an EU member state that is only gaining experience. The answer to the question - is it a balanced logical manifestation of the impact of a small country or only a fragmentary and accidental phenomenon? - could be supplied by research boasting a more comprehensive and much broader sample. 


\section{Literature}

\section{Official documents}

2007 m. birželio 11 d. Lietuvos Respublikos užsienio reikalų ministro įsakymas Nr. V-63 "Dèl užsienio reikalų ministerijos atstovų, kurie pristato Lietuvos Respublikos poziciją Europos Sajungos Tarybos, Europos Komisijos komitetuose ir darbo grupèse, sąrašų patvirtinimo". [The Order of 11 June 2007 No. V-63 by the Minister of Foreign Affairs of the Republic of Lithuania "On the Approval of the Lists of Representatives of the Ministry of Foreign Affairs who Present the Position of the Republic of Lithuania in the Committees and Working Parties of the Council of the European Union and the European Commission"] - in Lithuanian.

\section{Academic literature}

1. Beyers J., Dierickx G., "Nationality and European Negotiations: The Working Groups of the Council of Ministers", European Journal of International Relations, 1997, vol. 3, no. 4, p. 435-471.

2. Beyers J., Dierickx G., "The Working Groups of the Council of the European Union: Supranational and Intergovernmental Negotiations", Journal of Common Market Studies, 1998, vol. 36, no. 3, p. 289-317.

3. Börzel T., "Organizing Babylon - on different conceptions of policy networks", $P u$ blic Administration, 1998, vol. 76, no. 2, p. 253-273

4. Bulmer S., Lequesne Ch., "New Perspectives on EU-Member State Relationships", Questions de recherche / Research in question, 2002, January, nº 4, p. 28, http://www. ceri-sciences-po.org/publica/question/qdr4.pdf, 2007-12-18.

5. Hanf K., Soetendorp B. Adapting to European Integration: Small States and the European Union, London and New York: Longman, 1998.

6. Hix S., "The Study of the European Community: The Challenge to Comparative Politics", West European Politics, 1994, vol. 17, no. 1, p. 1-30.

7. Kassim H., "Policy Networks, Networks and European Union Policy Making: A Sceptical View", West European Politics, 1994, vol. 17, no. 4, p. 15-27.

8. Maniokas K., Vilpišauskas R., Žèruolis D., The Path of Lithuania to the European Union. The Unification of Europe and the Negotiations of Lithuania on the Membership of the European Union,Vilnius: Eugrimas, 2004.

9. Marks G., Hooghie L., Blank K., "European Integration from the 1980s: State-Centric v. Multi-level Governance", Journal of Common Market Studies, 1996, vol. 34, no. 3, p. 341-378. 